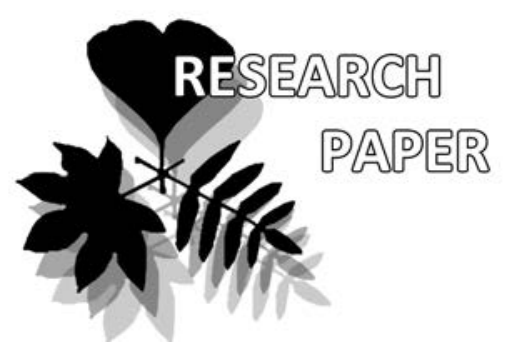

\section{Temporal climate and vegetation gradient of the Paleocene in the Amur Region (Far East of Russia)}

\author{
Olesya V. Bondarenko ${ }^{1}$, Torsten Utescher ${ }^{2,3}$, Nadezhda I. Blokhina ${ }^{1 *}$, \\ Tatiyana A. Evstigneeva ${ }^{1}$ \& Tatiyana V. Kezina ${ }^{4}$,
}

Olesya V. Bondarenko ${ }^{1}$

e-mail: laricioxylon@gmail.com

Torsten Utescher ${ }^{2,3}$

e-mail: t.utescher@uni-bonn.de

Nadezhda I. Blokhina ${ }^{1 *}$

e-mail: blokhina@biosoil.ru

Tatiyana A. Evstigneeva ${ }^{1}$

e-mail: evstigneeva@biosoil.ru

Tatiyana V. Kezina ${ }^{4}$

e-mail: tkezina@mail.ru

${ }^{1}$ Federal Scientific Center of the East Asia Terrestrial Biodiversity FEB RAS,

Vladivostok, Russia

${ }^{2}$ Senckenberg Research Institute and Natural History Museum, Frankfurt M., Germany

${ }^{3}$ Steinmann Institute, University of Bonn, Bonn, Germany,

${ }^{4}$ Amur State University, Blagoveshchensk, Russia

* corresponding author

Manuscript received: 12.05 .2020

Review completed: 10.08 .2020

Accepted for publication: 18.08.2020

Published online: 21.08.2020

Electronic Appendix:

http://www.geobotanica.ru/bp/

2020_09_02/BP_2020_9_2_bondarenko_ app_bondarenko_e_suppl.xlsx

\begin{abstract}
A B S T R A C T
Paleocene climate and vegetation evolution in the Amur Region (Far East of Russia) are quantitatively studied for the first time in detail, based on a palaeobotanical record. Palaeobotanical data for this time interval were obtained from a total of 25 palynofloras from Core 154 drilled in the Erkovetskii Brown Coal Field. In this first integrative study we apply the Coexistence Approach (CA) for quantification of palaeoclimate, the Plant Functional Types (PFT) approach and Integrated Plant Record (IPR) vegetation analysis for quantification of palaeovegetation. Our investigation documents the persistence of warm to cool temperate, overall humid climate conditions throughout the Paleocene. The reconstructed temperature records indicate relatively cool conditions for the early Paleocene part of the succession near the K-T boundary combined with distinctly seasonal conditions. The late $\mathrm{Pa}-$ leocene samples reveal a distinct warming trend and a tendency to more equal climate conditions that can be correlated with declining oxygen isotope values observed in marine archives. Our climate data indicate a relatively strong seasonality in precipitation suggesting the existence of a proto-monsoon in the Amur Region during the Paleocene. Vegetation data as reconstructed are in good agreement with the climate evolution. Based on PFT diversity spectra, our data indicate the prevalence of mixed evergreen-deciduous forests of warm temperate character. Based on the IPR method, plant biomes varied from the mixed mesophytic forest / mixed broadleaved evergreen forest ecotone in the warmer parts to the broadleaved deciduous forest / mixed mesophytic forest ecotone in the cooler parts of the studied sedimentary succession.
\end{abstract}

Ke y words : temperature evolution, precipitation pattern, monsoon intensity, structure of plant assemblages, vegetation type

\section{P E 3 Ю M E}

Бондаренко О.В., Утешер Т., Бмохина Н.И., Евстигнеева Т.А., Кезина Т.В. Временной градиент климата и растительности Амурской обмасти (АаАьний Восток России) в палеоцене. Эволюция климата и растительности Амурской области (Аальний Восток России) в палеоцене впервые детально количественно изучена на основе палеоботанических данных. Памеоботанические Аанные Аля этого временного интерваца были получены на основе анализа 25 палинофлор из керна 154, пробуренного в Ерковецком буроугольном месторожАении. В этом первом комплексном исследовании мы применяем метод Coexistence Approach (CA) Аля количественной оценки палеоклимата, Plant Functional Tyреs (PFT) подход и Integrated Plant Record (IPR) анализ - Аля количественной оценки палеорастительности. Наше исследование Аокументирует сохранение тёплых до прохлацно умеренных, в ажных климатических условий в течение всего палеоцена. Реконструированные температурные параметры указывают на относительно прохладные условия Аля раннего палеоценового участка сукцессии вблизи мел - палеогеновой границы в сочетании с отчётливо сезонными условиями. В позАних палеоценовых образцах прослеживается отчётливая тенденция потепления и тенденция к более ровным климатическим условиям, которые могут быть связаны с уменьшением значений изотопов кислорода, наблюдаемых в морских отложениях. Наши климатические данные указывают на относительно сильно выраженную сезонность осадков, предполагающую существование прото-муссона в Амурской области в палеоцене. Реконструированные Аанные о растительности хорошо согласуются с эволюцией климата. Наши Аанные спектров разнообразия РFT указывают на распространение смешанных

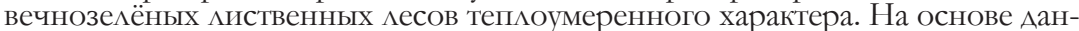
ных метода IPR, биомы растений варьировали от экотона межАу смешанным мезофитным / смешанным широколиственным вечнозелёным Аесом в более тёплых частях до экотона межАу широколиственным Аистопадным / смешанным мезофитным Аесом в более холодных частях изученной осадочной сукцессии.

КАючевые слова: Аинамика температуры, характер осадков, интенсивность муссона, структура растительных сообществ, тип растительности 


\section{INTRODUCTION}

The Paleocene, as the first geological epoch of the Paleogene, lasted from about 66 to $56 \mathrm{Ma}$ and was bracketed by two major dramatic events in Earth's history: a mass extinction and a rapid global warming. The mass extinction event started at the end of the Cretaceous (66.02 Ma), known as the Cretaceous - Paleogene boundary (KPB). Rapid climate warming in the last $350 \mathrm{kyr}$ of the Maastrichtian and climate cooling during the first $500 \mathrm{kyr}$ of the early Paleocene are linked to a large impact of the Chicxulub asteroid and Deccan volcanic eruptions (Schulte et al. 2019, Punekar et al. 2014). The end of the Paleocene was marked by one of the fastest and most extreme global warming events recorded in geological history. It was a geologically brief interval known as either the Paleocene - Eocene Thermal Maximum (PETM) or the Initial Eocene Thermal Maximum (IETM). The PETM event (55.8 $\pm 0.2 \mathrm{Ma}$ ) lasted $\sim 170 \mathrm{ky}$, and it is commonly attributed to North Atlantic Igneous Province (NAIP) volcanism and methane degassing of seafloor sediments (e.g., Dickens et al. 1995, Dickens 2000, Westerhold et al. 2009, Charles et al. 2011, Wieczorek et al. 2013, Gutjahr et al. 2017, Morgan et al. 2019, Jones et al. 2019). The PETM brought about noticeable biotic changes, such as extinction, appearance, blooming and / or diversification of various ocean and land-dwelling organisms. Besides, the late Paleocene - early Eocene ( $\sim 56$ $51 \mathrm{Ma}$ ) interval was a critical phase in the history of the India-Asia convergence. This major tectonic event, the India-Asia collision, contributed to the uplift of the Tibetan Plateau, and the last has triggered the trend of decreasing atmospheric $\mathrm{CO}_{2}$ concentration and major change in global climate in the Eocene (e.g. Clementz et al. 2011, Meng et al. 2012, Najman et al. 2017, Wang et al. 2018).

Globally, Paleocene climate was relatively stable, warm and moist. The Polar Regions were ice-free and covered with coniferous and deciduous forests (Willis \& McElwain 2002). These Paleocene polar forests grew in winter darkness and mesothermal humid climate (Willard et al. 2019). Those were very low diversity forests with little habitat variation, very few climbers and more open structure (Collinson \& Hooker 2003). The warm temperatures worldwide gave rise to thick tropical, subtropical and deciduous forest cover around the globe. Paleocene forests were probably denser than those of the Cretaceous. First angiosperms, seen in the Cretaceous, continued to develop and proliferate. In general, the Paleocene is marked by the development of modern plant species, cacti and palm trees appeared (Collinson 1990, 2000, 2001). Thus, Paleocene floras provide the potential for detailed interpretation of plant biomes and their response to global change such as warm climate thermal maxima and tectonic events, and the knowledge of the vegetation evolution during the Paleocene provides unique perspectives for the modeling of actual global changes and helps to probe into the integrated response of the Earth system to various driving forces (Utescher et al. 2009, Zachos et al. 2008).

Today, the Amur Region is located in the south of the Russian Far East (RFE) in the transition zone of continental and oceanic climates and its vegetation belongs to the con- tinental-transition group of ecosystems with a monsoon climate (Naprasnikov et al. 1983). Due to the considerable remoteness from the Pacific Ocean (about $1200 \mathrm{~km}$ ), the climate has pronounced features of continentality: large fluctuations of daily and annual temperatures, low winter and negative mean annual temperatures. In the cold season, air masses coming from Eastern Siberia, Mongolia, and from the Arctic Ocean dominate here while during summer winds blow from the Pacific Ocean bringing the major part of annual precipitation. Such distribution in the conditions of mountainous terrain, for example, the middle and upper parts of the Zeya River basin, causes river floods and often catastrophic flooding (Naprasnikov et al. 1983).

At present, a large part of the Amur Region is occupied by light coniferous taiga. Dark coniferous forests grow mainly in the east and northeast of the region. Zonal taiga forests are replaced in places by derivative birch forests. In the south of the region, various nemoral forests (the floral composition of nemoral vegetation formed in the Cenozoic (Turgai flora) from deciduous and coniferous species and herbaceous perennials) have remained representing an extremely depleted derivative of the Turgai flora. In the extreme southeast, nemoral vegetation is represented by cedar-broadleaved taiga with significant participation of relict “Tertiary" species (Starchenko 2009, Borisova \& Starchenko 2018). The specifics of the flora and vegetation of the Amur Region are mainly associated with two factors: the belonging of the main part of the region to the Amur Basin and the location of the region on the border of the East Asian and Circum-Boreal floristic regions; the influence of the Pacific Ocean can be traced in the southern, central and eastern parts of the Amur Region (Starchenko 2009, Borisova \& Starchenko 2018).

The evolution of the Paleogene (including Paleocene) climate and vegetation in East Eurasia in general and the Amur Region in particular is tied to global climate change, changes in regional palaeogeography and ocean currents, and the history of the East Asian monsoon (EAM), the emergence of which was promoted by the rise of the Tibetan Plateau (e.g., Akhmetiev 2004, 2015, Akhmetiev \& Zaporozhets 2017, An et al. 2001, Liu \& Yin 2002, Liu et al. 2015, Quan et al. 2012a, b, Sato et al. 2006, Tada et al. 2016, Yamamoto \& Hoang 2009). Climate and vegetation in the Paleocene can be reconstructed from the palaeobotanical record. The Amur Region is one of the RFE regions, where large burials of Paleogene plants are concentrated, therefore the Paleogene (including Paleocene) floras of this region were subject to various taxonomic and stratigraphic studies the results of which were presented in the works of Akhmetiev (1973), Akhmetiev et al. (1969, 2002), Brattseva (1969), Kamaeva (1990), Kezina (2000, 2004, 2005), Kezina \& Litvinenko (2007), Kezina \& Ol'kin (2000), Krassilov (1976), Mamontova (1975, 1977), Varnavskii et al. (1988), Zaklinskaya et al. (1977), Ziva (1973), and others. However, these works are mainly devoted to the description of plant fossil remains, new fossil taxa, taxonomic diversity of plants, or palaeofloristic aspects. At the same time the knowledge on climate and vegetation dynamics in the Paleocene is still very poor and fragmentary. 
For the RFE in general, our knowledge is mainly based on qualitative interpretations of macro- and microfloral successions, while quantitative studies were largely missing so far. Recently, quantitative palaeoclimate and vegetation studies were conducted on the Paleogene of the neighboring Primorye which unravelled major spatio-temporal changes (Bondarenko et al. 2019, 2020a, b) but revealed few details only as regards the evolution in the Paleocene.

Here we present a first higher-resolving time series for the climate and vegetation evolution of the Amur Region during the Paleocene. Our study is based on the investigation of 25 palynofloras sampled from a well that was cored through a complete Paleocene sedimentary sequence. We analyze changes in the taxonomic composition of the floras and the abundance of floral components and establish quantitative records to trace regional climate and vegetation dynamics at the time when first Cenozoic ecosystems became established. Moreover, we discuss potentially monsoon-induced patterns and how global signals manifested themselves in the Amur Region.

\section{STUDY AREA}

\section{Sedimentary succession in the study area}

The Erkovetskoe Brown Coal Field is located in the northwestern part of the Zeisko-Bureinskii Basin in the Amur Region of the RFE (Fig. 1A). The relief of the Coal Field is a flat plain, weakly dissected by a modern river system, with absolute heights of 190-250 m. The deposits are mapped by numerous cores (Fig. 1B).

The sediments of the Tsagayanskaya Formation, unconformably lying on older deposits of the Lower and Middle Cretaceous (Poyarkovskaya and Zavitinskaya formations), have a wide regional extension. The total thickness of the formation exceeds $300 \mathrm{~m}$. Lithologically, the Tsagayanskaya Formation is subdivided into three subformations: the Lower Tsagayanskaya, Middle Tsagayanskaya and Upper Tsagayanskaya subformations including the Kivdinskie layers (Fig. 1C).

The sediments of the Late Cretaceous Middle Tsagayanskaya subformation exposed in the Erkovetskoe Brown Coal Field are represented by dense clays composed of kaolin and montmorillonite, at places sandstones, sands, siltstones and layers of carbonaceous clays of greenish-gray and light gray color. Argillites are finely laminated and contain plant detritus. Interlayers and local brown coal lenses are found among clays and siltstones. The thickness varies from $20-35$ to $170 \mathrm{~m}$.

The early Paleocene Upper'Tsagayanskaya subformation, which includes the late Paleocene Kivdinskie layers, is represented by a series of intermittent sand, siltstone and carbonaceous clay, overlying the sediments of the Middle Tsagayanskaya subformation without a visible discontinuity. The thickness of the subformation varies from 20 to $110 \mathrm{~m}$. The upper part of the subformation includes a brown coal layer $(6-9 \mathrm{~m})$, its base smoothly dipping to the south. Palynologically, the Upper Tsagayanskaya subformation was studied by Kezina and Litvinenko (Kezina 2005, Kezina \& Litvinenko 2007).

The lower part of the Upper Tsagayanskaya subformation is predominantly sandy. Its upper, coal-bearing part concordantly overlies the strata and that part has been denoted as Kivdinskie layers (Akhmetiev et al. 2002). The thickness of Kivdinskie layers usually attains 20-30, at some places 40-60 m. The brown coals of the Kivdinskie layers are overlain by homogeneous laminated clays, forming the topmost part of the Upper Tsagayanskaya subformation. Palynologically, the Kivdinskie layers were studied by Kezina and Litvinenko (Kezina 2005, Kezina \& Litvinenko 2007).

In the central and northeastern parts of the sedimentary basin, the Kivdinskie layers are unconformably overlain by alluvial and lacustrine-alluvial sandy sediments of the early Eocene Raychikhinskaya Formation. In the Core 154, the Kivdinskie layers are covered by the Oligocene Mukhinskaya Formation.

\section{Stratigraphy and dating}

Biostratigraphic studies on the Tsagayanskaya Formation, which is the most renowned stratigraphic unit of the Amur Region, started more than a century ago. The problems concerning stratigraphy and nomenclature ranks of these Cretaceous to Paleogene deposits as well as the position of the Cretaceous-Paleogene boundary have been addressed in various studies (Yavorovsky 1911, Muzylev 1948, Fin'ko \& Zaklinskaya 1958, Chemekov et al. 1960, Brattseva 1962, 1964, 1965, 1969, Kryshtofovich \& Baikovskaya 1966, Ziva 1973, Krassilov 1976, Mamontova 1977, Zaklinskaya et al. 1977, Kamaeva 1990, Krasnyi ed. 1994, Bugdaeva et al. 2001, Akhmetiev et al. 2002, Sun et al. 2002, 2005, 2011, 2014, Markevich et al. 2004, 2011, Kezina 2005, 2011, Kezina \& Litvinenko 2007, Herman et al. 2009, Hao et al. 2010, Moiseeva et al. 2018, and others). The formation of ideas about the structure and age of the Tsagayanskaya Formation and its subunits is exemplified in Fig. 2, based on selected works.

Recently, isotope dating was obtained for a rhyolithic tuff from the upper part of the Middle Tsagayanskaya subformation in the stratotype section of the Tsagayanskaya Formation (Ploskaya Mt.). Fission-track dating revealed an age of $61.7 \pm 2.1 \mathrm{Ma}$ (Suzuki 2004), whereas using U-Pb analysis, the age of this tuff layer was estimated as $66 \pm 1 \mathrm{Ma}$ (Knittel et al. 2013). Ages of $68.0 \pm 0.96 \mathrm{Ma}$ (U-Pb dating) were obtained from the same tuff layer at Ploskaya Mt. by Markevich et al. (2014). The isotope age of the rhyolithic tuff in the Baishantou section, exposed on the right bank of the Amur (Heilongjiang) River in China, according to Li et al. (2004), is $66 \pm 1 \mathrm{Ma}(\mathrm{U}-\mathrm{Pb}$ dating). Ages of $64.1 \pm 0.7 \mathrm{Ma}$ (U-Pb method) and $61.7 \pm 1.8 \mathrm{Ma}$ (fissiontrack dating) were obtained for the tuff layer in the lower part of Baishantou section by Suzuki et al. (2011).

Here we follow the stratigraphic concept of Moiseeva et al. (2018) (cf. Fig. 2).

\section{MATERIAL AND METHODS Floral record}

In the present study, microfloras (PFs) from 25 depth levels sampled from Core $154\left(50^{\circ} 48^{\prime} \mathrm{N} 128^{\circ} 43^{\prime} \mathrm{E}\right)$ are analysed covering the Upper Tsagayanskaya subformation and Kivdinskie layers in the Erkovetskoe Brown Coal Field (Fig. 1). All palynological data are taken from Kezina (2005) 


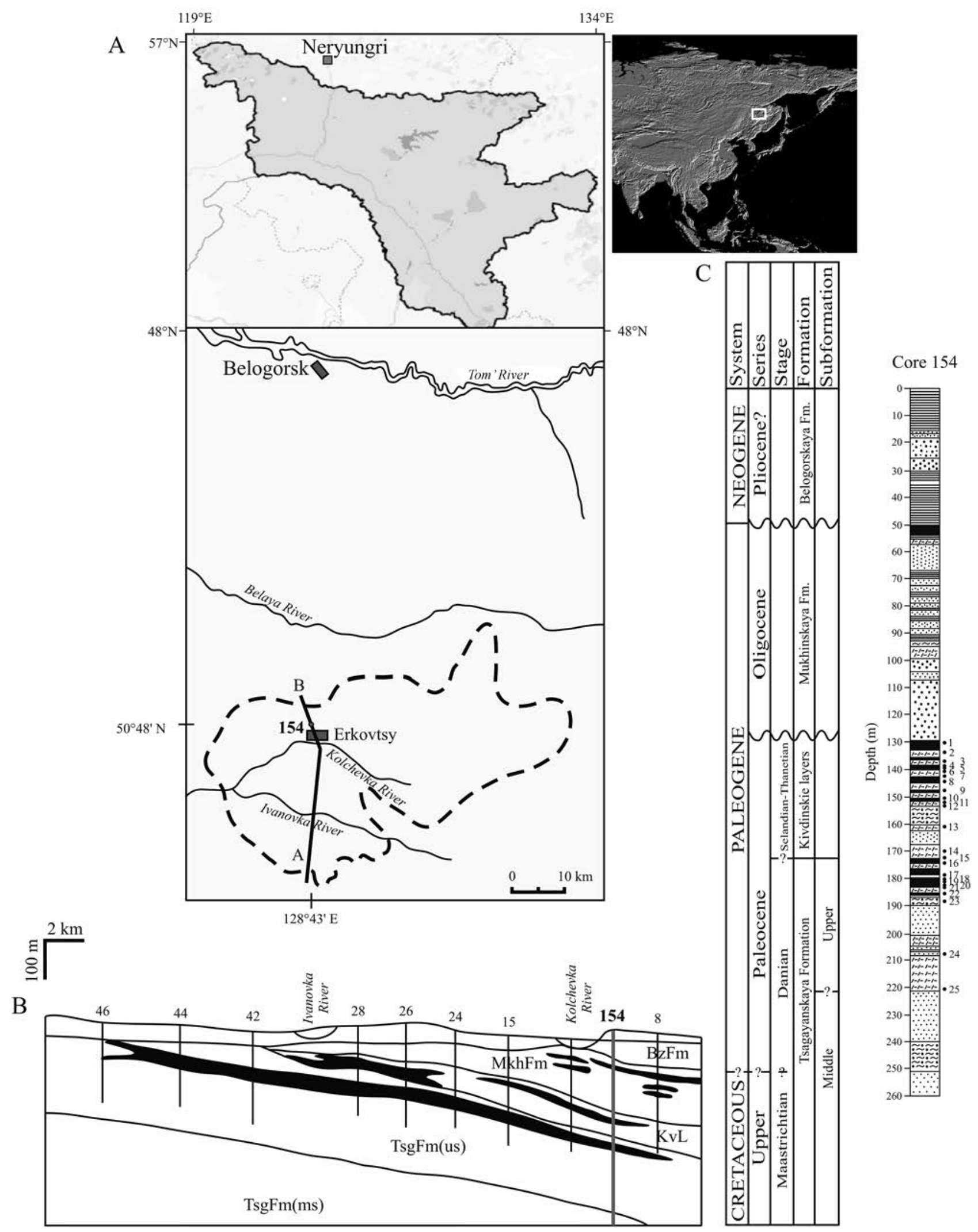

滋.

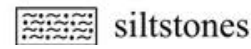
coal
$\cdot 1$ palynofloras

Figure 1 Map showing the location of the Amur Region and the location of the studied Core $154(\mathrm{~A})$, section of the sediments on the line A-B (B), lithological profile of the studied Core 154 and levels of palynofloras (C): Dotted line - contour of the Erkovetskii Brown Coal Field after Kezina (2005) and Kezina \& Litvinenko (2007), TsgFm(ms) - Tsagayanskaya Formation (middle subformation), TsgFm(us) - Tsagayanskaya Formation (upper subformation), KvL - Kivdinskie layers, MkhFm - Mukhinskaya Formation, BzFm - Buzulinskaya Formation 
and Kezina \& Litvinenko (2007). The microfloras yield evidence for a total of 90 different taxa (56 angiosperms, 16 gymnosperms and 18 pteridophytes) identified by Kezina (Kezina 2005, Kezina \& Litvinenko 2007). As reported in the original studies, 350 pollen grains were counted per sample. The material was collected by and is stored in the Institute of Tectonics and Geophysics (ITG FEB RAS, Khabarovsk) in 1970s for conducting complex studies in the territory of the Zeisko-Bureinskii Basin.

\section{Palynological method}

The palynological data are represented in diagrams (Fig. 4) constructed with the TILIA program (Grimm 2011). The diagrams were divided into zones using Constrained Incremental Sums of Squares cluster analysis (CONISS) to formally estimate variations in the record. The percentage of each taxon and sub-sums were calculated based on the total sum of pollen and spores.

\section{Quantitative palaeoclimate reconstruction: Coexistence Approach (CA)}

To reconstruct climate from the palynomorph records we used the Coexistence Approach (CA) (Mosbrugger \& Utescher 1997, Utescher et al. 2014). This approach is organ-independent, so that both macro- and microfossil plants are eligible as long as their modern botanical affinities are determinable (Mosbrugger \& Utescher 1997, Utescher et al. 2007, Bruch et al. 2011). For detailed description of the method the reader is referred to the original papers describing the procedure (Mosbrugger \& Utescher 1997, Utescher et al. 2014). We use data sets from the Palaeoflora Database (Utescher \& Mosbrugger 2018). Floral lists with corresponding nearest living relatives (NLRs) employed in this study and their climatic requirements are made available in Supplementary electronic information 1.

In this study, three temperature and four precipitation variables are reconstructed: mean annual temperature (MAT), cold and warm month mean temperature (CMMT, WMMT), mean annual precipitation (MAP), and mean monthly precipitation of the wettest, driest and warmest month (MPwet, MPdry, and MPwarm). Mean values of climatic parameters for each depth level are given in Table 1.

In the CA, at least 10 NLR taxa contributing with climate data are required to obtain reliable results (Mosbrugger \& Utescher 1997). The climatic resolution of the CA results also depends on the taxonomical level of NLR identification (Mosbrugger \& Utescher 1997). Eucommia ulmoides Oliver, Ginkgo biloba L. and Sciadopitys verticillata (Thunb.) Siebold et Zucc. were excluded from the analysis for being monotypic taxa. For Ericaceae Juss. and Rosaceae Juss. no data are at disposal. For the monotypic genera (but not monotypic families) we use climate data for families (for example, climate data of Myricaceae Blume were used for Comptonia peregrina (L.) Coult., Taxodioideae Endl. ex K. Koch - for Glyptostrobus pensilis (Staunton ex D. Don) K. Koch and Taxodium Richard).

\section{Climate seasonality, monsoon intensity}

In order to determine temperature seasonality of the Paleocene climate of the Amur Region, the mean annual range of temperature (MART) was calculated as the difference of WMMT and CMMT for each level (Table 2, Fig. 3). To study precipitation seasonality, the mean annual

Table 1. Mean values of climatic parameters for each depth level. Means by each depth level (calculated using coexistence interval means). MAT - mean annual temperature; CMMT - cold month mean temperature; WMMT - warm month mean temperature; MAP - mean annual precipitation; MPwet - mean monthly precipitation of the wettest month; MPdry - mean monthly precipitation of the driest month; MPwarm - mean monthly precipitation of the warmest month.

\begin{tabular}{|c|c|c|c|c|c|c|c|c|c|c|}
\hline $\begin{array}{l}\text { Depth, } \\
\text { m }\end{array}$ & Flora & $\begin{array}{l}\text { Taxa with } \\
\text { climate data }\end{array}$ & $\begin{array}{l}\% \text { of } \\
\text { coexistence }\end{array}$ & $\underset{{ }^{\circ} \mathrm{C}}{\mathrm{MAT}}$ & $\begin{array}{l}\text { CMMT, } \\
{ }^{\circ} \mathrm{C}\end{array}$ & $\begin{array}{l}\text { WMMT, } \\
{ }^{\circ} \mathrm{C}\end{array}$ & $\begin{array}{l}\text { MAP, } \\
\mathrm{mm}\end{array}$ & $\begin{array}{l}\text { MPwet, } \\
\text { mm }\end{array}$ & $\begin{array}{l}\text { MPdry, } \\
\text { mm }\end{array}$ & $\begin{array}{l}\text { MPwarm, } \\
\text { mm }\end{array}$ \\
\hline \multicolumn{11}{|c|}{ Late Paleocene } \\
\hline 130.2 & PF1 & 18 & 100 & 18.8 & 11.7 & 26.0 & 1296 & 195 & 53 & 149 \\
\hline 133.0 & PF2 & 30 & 100 & 18.0 & 10.7 & 25.3 & 1296 & 247 & 42 & 158 \\
\hline 136.6 & PF3 & 33 & 99.6 & 18.1 & 10.3 & 25.5 & 1278 & 246 & 27 & 148 \\
\hline 138.2 & PF4 & 34 & 99.6 & 19.0 & 10.8 & 25.6 & 1296 & 197 & 42 & 158 \\
\hline 138.6 & PF5 & 28 & 99.5 & 19.0 & 11.8 & 25.6 & 1296 & 249 & 42 & 158 \\
\hline 140.2 & PF6 & 34 & 100 & 18.5 & 10.8 & 25.5 & 1407 & 251 & 38 & 158 \\
\hline 142.2 & PF7 & 36 & 99.6 & 18.4 & 10.3 & 25.7 & 1334 & 260 & 29 & 148 \\
\hline 143.3 & PF8 & 31 & 99.5 & 19.0 & 10.8 & 25.6 & 1296 & 197 & 42 & 158 \\
\hline 146.4 & PF9 & 24 & 100 & 19.0 & 11.8 & 25.6 & 1202 & 250 & 44 & 96 \\
\hline 150.5 & PF10 & 20 & 100 & 19.0 & 11.7 & 25.6 & 1740 & 270 & 37 & 171 \\
\hline 151.4 & PF11 & 35 & 99.6 & 18.1 & 10.3 & 25.5 & 1278 & 198 & 29 & 148 \\
\hline \multicolumn{11}{|c|}{ Early Paleocene } \\
\hline 152.6 & PF12 & 31 & 99.5 & 17.8 & 10.9 & 25.2 & 1296 & 236 & 42 & 158 \\
\hline 161.2 & PF13 & 24 & 100 & 18.3 & 10.8 & 25.5 & 1296 & 235 & 42 & 158 \\
\hline 170.0 & PF14 & 26 & 99.4 & 17.0 & 10.3 & 25.2 & 1278 & 249 & 27 & 148 \\
\hline 172.6 & PF15 & 25 & 100 & 17.0 & 10.2 & 24.2 & 1176 & 262 & 27 & 134 \\
\hline 174.3 & PF16 & 24 & 100 & 16.5 & 10.3 & 23.8 & 1184 & 177 & 29 & 81 \\
\hline 179.4 & PF17 & 27 & 100 & 17.0 & 8.2 & 25.6 & 1115 & 219 & 27 & 126 \\
\hline 180.2 & PF18 & 18 & 100 & 17.2 & 7.5 & 25.0 & 1659 & 233 & 42 & 147 \\
\hline 181.2 & PF19 & 21 & 99.3 & 17.0 & 10.3 & 25.3 & 1278 & 197 & 27 & 148 \\
\hline 183.1 & PF20 & 16 & 100 & 16.5 & 10.3 & 25.1 & 1184 & 219 & 27 & 78 \\
\hline 183.5 & PF21 & 24 & 100 & 17.0 & 7.7 & 25.3 & 1278 & 197 & 27 & 148 \\
\hline 185.5 & PF22 & 21 & 100 & 17.0 & 6.8 & 25.4 & 1278 & 197 & 27 & 148 \\
\hline 188.3 & PF23 & 24 & 99.4 & 16.4 & 11.1 & 25.3 & 1352 & 249 & 39 & 155 \\
\hline 207.4 & PF24 & 25 & 99.4 & 18.4 & 10.3 & 25.3 & 1334 & 265 & 27 & 148 \\
\hline 220.1 & PF25 & 27 & 100 & 17.0 & 6.8 & 25.7 & 1278 & 246 & 27 & 148 \\
\hline
\end{tabular}




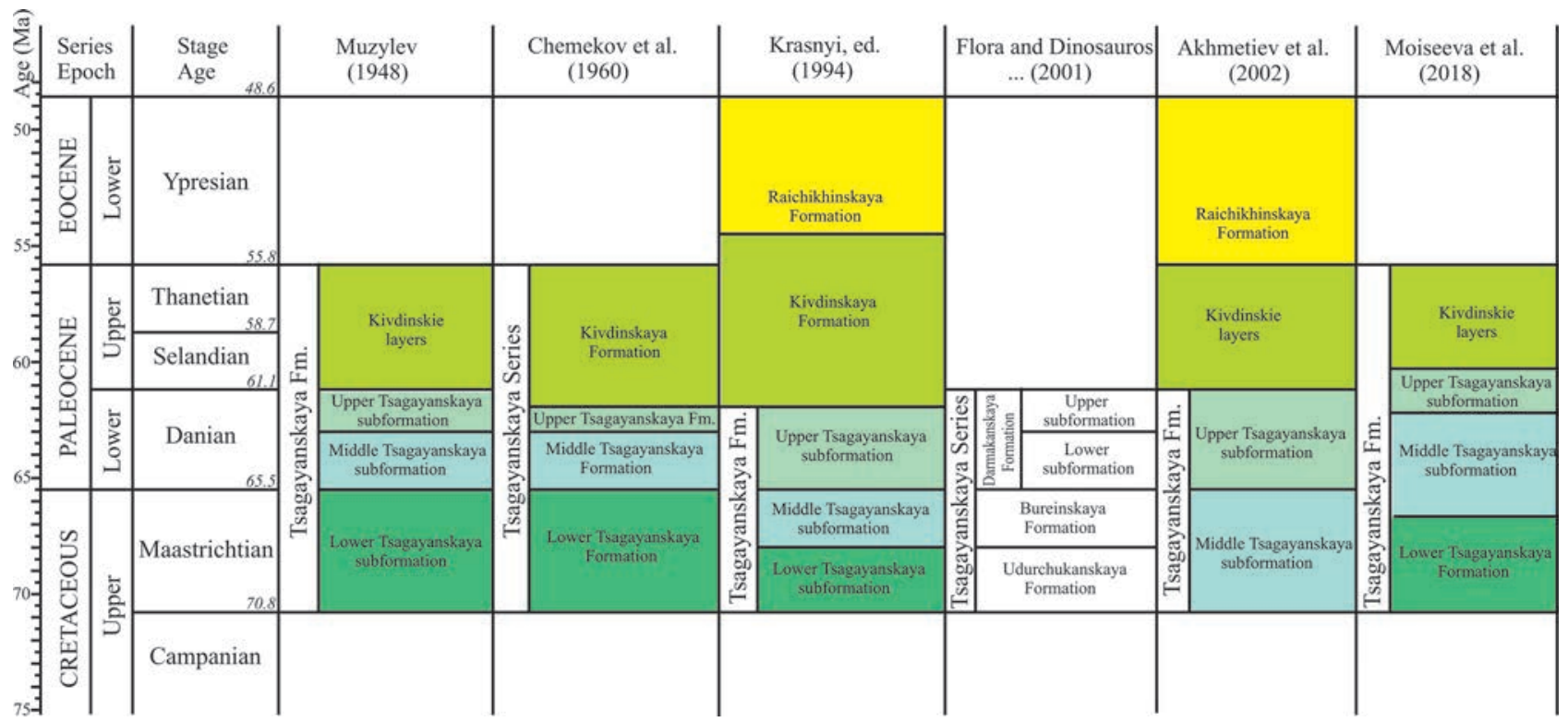

Figure 2 Chart with the formation names discussed in the text showing the different stratigraphic interpretations of the Tsagayanskaya Formation and its subunits

range of precipitation (MARP - calculated as difference of MPwet and MPdry) was calculated (Table 2, Fig. 3). To obtain an estimate of the EAM intensity during Paleocene we use the ratio of MPwet and MPdry on MAP (RMPwet and RMPdry) (Table 2). According to Jacques et al. (2011), the ratios of MPwet and MPdry of MAP provide a good indication of past monsoon intensity (summer - EASM and winter - EAWM respectively). The monsoon is a complex climatic phenomenon, nevertheless, in general increasing of RMPwet, i.e. higher proportion of precipitation in the wet season, may indicate an intensification of EASM, while the decreasing of RMPdry, i.e. lower proportion of precipitation in the dry season, suggests an intensification of EAWM.

Table 2. Temperature and precipitation seasonality parameters and related values. Means by each depth level (calculated using coexistence interval means). MAT - mean annual temperature; CMMT - cold month mean temperature; WMMT warm month mean temperature; MRAT - mean annual range of temperature (MART = WMMT - CMMT); MAP - mean annual precipitation; MPwet - mean monthly precipitation of the wettest month; MPdry - mean monthly precipitation of the driest month; MARP - mean annual range of precipitation (MARP = MPwet - MPdry); RMPwet - ratio of MPwet on MAP (RMPwet $=$ MPwet/MAP*100); RMPdry - ratio of MPdry on MAP (RMPdry = MPdry/MAP*100).

\begin{tabular}{|c|c|c|c|c|c|c|c|c|c|c|c|}
\hline $\begin{array}{l}\text { Depth, } \\
\text { m }\end{array}$ & Flora & $\begin{array}{l}\text { MAT } \\
\text { mean, } \\
{ }^{\circ} \mathrm{C}\end{array}$ & $\begin{array}{l}\text { CMMT } \\
\text { mean, } \\
{ }^{\circ} \mathrm{C}\end{array}$ & $\begin{array}{l}\text { WMMT } \\
\text { mean, } \\
{ }^{\circ} \mathrm{C}\end{array}$ & $\begin{array}{l}\text { MART, } \\
{ }^{\circ} \mathrm{C}\end{array}$ & $\begin{array}{l}\text { MAP } \\
\text { mean, } \\
\text { mm }\end{array}$ & $\begin{array}{l}\text { MP } \\
\text { wetmean, } \\
\text { mm }\end{array}$ & $\begin{array}{l}\text { MP } \\
\text { drymean, } \\
\text { mm }\end{array}$ & $\begin{array}{l}\text { MARP, } \\
\text { mm }\end{array}$ & $\begin{array}{l}\text { RMP } \\
\text { wet, } \\
\%\end{array}$ & $\begin{array}{l}\text { RMP } \\
\text { dry, } \\
\%\end{array}$ \\
\hline \multicolumn{12}{|c|}{ Modern } \\
\hline- & - & 0.3 & -24.2 & 21.0 & 45.2 & 578 & 135 & 5 & 130 & 23.3 & 0.9 \\
\hline \multicolumn{12}{|c|}{ Late Paleocene } \\
\hline 130.2 & PF 1 & 18.8 & 11.7 & 26.0 & 14.3 & 1296 & 195 & 53 & 142 & 15.0 & 4.1 \\
\hline 133.0 & PF 2 & 18.0 & 10.7 & 25.3 & 14.6 & 1296 & 247 & 42 & 205 & 19.0 & 3.2 \\
\hline 136.6 & PF 3 & 18.1 & 10.3 & 25.5 & 15.2 & 1278 & 246 & 27 & 219 & 19.2 & 2.1 \\
\hline 138.2 & $\mathrm{PF} 4$ & 19.0 & 10.8 & 25.6 & 14.8 & 1296 & 197 & 42 & 155 & 15.2 & 3.2 \\
\hline 138.6 & PF 5 & 19.0 & 11.8 & 25.6 & 13.8 & 1296 & 249 & 42 & 207 & 19.2 & 3.2 \\
\hline 140.2 & PF 6 & 18.5 & 10.8 & 25.5 & 14.4 & 1407 & 251 & 38 & 213 & 17.8 & 2.7 \\
\hline 142.2 & PF 7 & 18.4 & 10.3 & 25.7 & 15.4 & 1334 & 260 & 29 & 231 & 19.5 & 2.2 \\
\hline 143.3 & PF 8 & 19.0 & 10.8 & 25.6 & 14.8 & 1296 & 197 & 42 & 155 & 15.2 & 3.2 \\
\hline 146.4 & PF 9 & 19.0 & 11.8 & 25.6 & 13.8 & 1202 & 250 & 44 & 206 & 20.8 & 3.7 \\
\hline 150.5 & PF 10 & 19.0 & 11.7 & 25.6 & 13.9 & 1740 & 270 & 37 & 233 & 15.5 & 2.1 \\
\hline 151.4 & PF 11 & 18.1 & 10.3 & 25.5 & 15.2 & 1278 & 198 & 29 & 169 & 15.5 & 2.3 \\
\hline \multicolumn{12}{|c|}{ Early Paleocene } \\
\hline 152.6 & PF 12 & 17.8 & 10.9 & 25.2 & 14.3 & 1296 & 236 & 42 & 194 & 18.2 & 3.2 \\
\hline 161.2 & PF 13 & 18.3 & 10.8 & 25.5 & 14.7 & 1296 & 235 & 42 & 193 & 18.1 & 3.2 \\
\hline 170.0 & PF 14 & 17.0 & 10.3 & 25.2 & 14.9 & 1278 & 249 & 27 & 222 & 19.5 & 2.1 \\
\hline 172.6 & PF 15 & 17.0 & 10.2 & 24.2 & 14.0 & 1176 & 262 & 27 & 235 & 22.3 & 2.3 \\
\hline 174.3 & PF 16 & 16.5 & 10.3 & 23.8 & 13.5 & 1184 & 177 & 29 & 148 & 14.9 & 2.4 \\
\hline 179.4 & PF 17 & 17.0 & 8.2 & 25.5 & 17.3 & 1115 & 219 & 27 & 192 & 19.6 & 2.4 \\
\hline 180.2 & PF 18 & 17.2 & 7.5 & 25.0 & 17.5 & 1659 & 233 & 42 & 191 & 14.0 & 2.5 \\
\hline 181.2 & PF 19 & 17.0 & 10.3 & 25.3 & 15.0 & 1278 & 197 & 27 & 170 & 15.4 & 2.1 \\
\hline 183.1 & PF 20 & 16.5 & 10.3 & 25.1 & 14.8 & 1184 & 219 & 27 & 192 & 18.5 & 2.3 \\
\hline 183.5 & PF 21 & 17.0 & 7.7 & 25.3 & 17.6 & 1278 & 197 & 27 & 170 & 15.4 & 2.1 \\
\hline 185.5 & PF 22 & 17.0 & 6.8 & 25.4 & 18.6 & 1278 & 197 & 27 & 170 & 15.4 & 2.1 \\
\hline 188.3 & PF 23 & 16.4 & 11.1 & 25.3 & 14.2 & 1352 & 249 & 39 & 210 & 18.4 & 2.9 \\
\hline 207.4 & PF 24 & 18.4 & 10.3 & 25.3 & 15.0 & 1334 & 265 & 27 & 238 & 19.9 & 2.0 \\
\hline 220.1 & PF 25 & 17.0 & 6.8 & 25.7 & 18.9 & 1278 & 246 & 27 & 219 & 19.2 & 2.1 \\
\hline
\end{tabular}



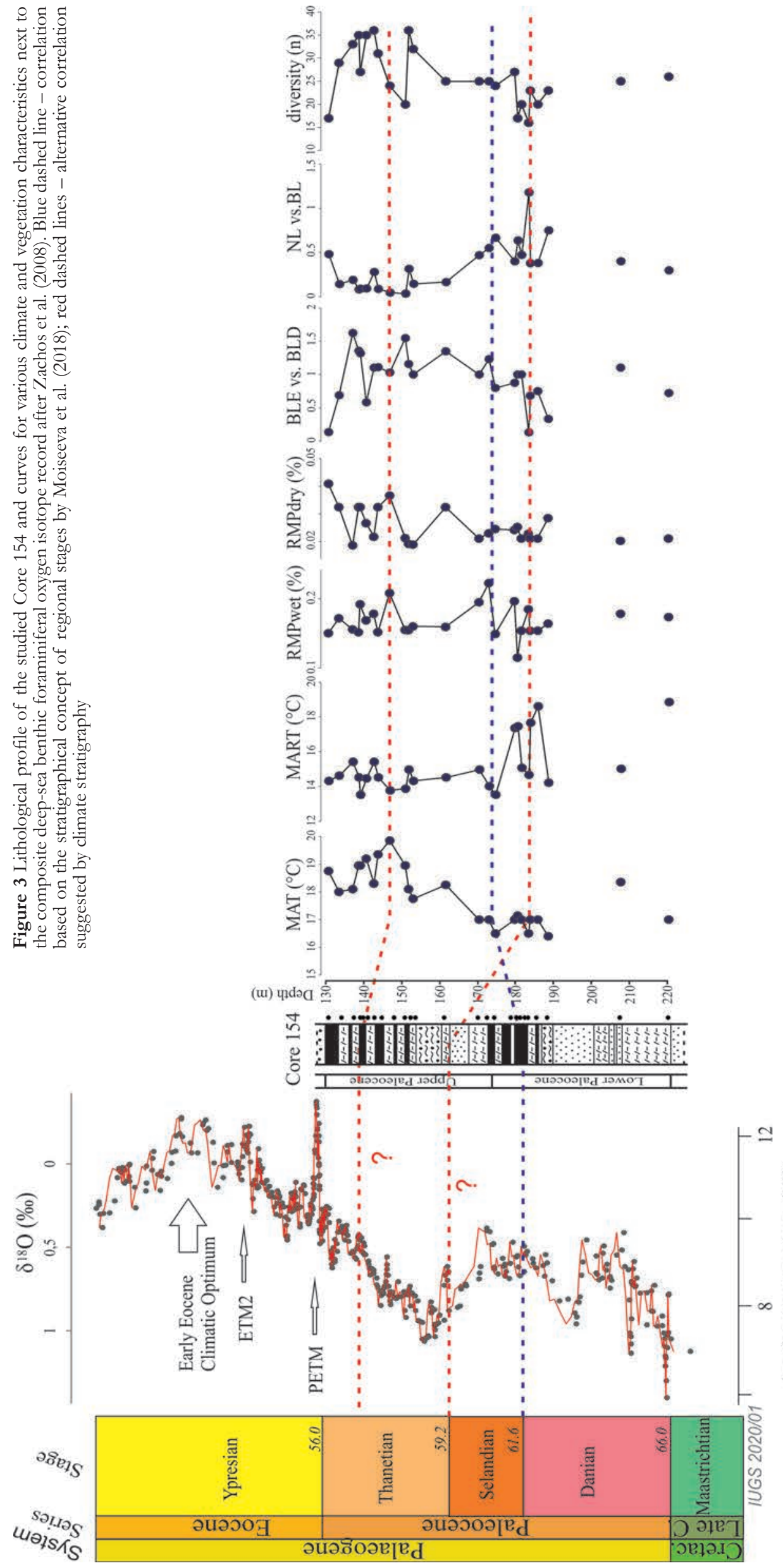

\section{Vegetation reconstruction methods}

In order to reconstruct palaeovegetation based on fossil flora, several methods have been developed aiming at standardized, reproducible and thus comparable results, facilitating the analysis of spatio-temporal trends in the evolution of the vegetation cover. These methods differ mainly by scale of reconstruction from local plant communities (PFT) to biome level (IPR).

\section{Quantitative \\ palaeovegetation \\ reconstruction: \\ Plant Functional Type (PFT) approach}

The Plant Functional Type (PFT) concept goes back to works of Prentice (e.g., Prentice et al. 1992, Prentice \& Webb 1998) and has been widely used to describe vegetation cover in vegetation modeling. A PFT is defined using traits and climatic thresholds of key taxa, and combines species related by morphological and phenological traits (François et al. 2011). The application of the PFT technique on the Neogene palaeobotanical record was first introduced by Utescher et al. (2007). The present study employs an extended PFT classification scheme described in details in Popova et al. (2013), comprising 26 herbaceous to arboreal PFTs based on physiognomic characters and bioclimatic tolerances of plants, complemented by an aquatic PFT (Table 3). The allocation of fossil taxa to the single PFTs is based on interpretation of their NLRs (Supplementary electronic information 2), and follows the procedure 
Table 3. Plant functional type classification used for the present study (Popova et al. 2013).

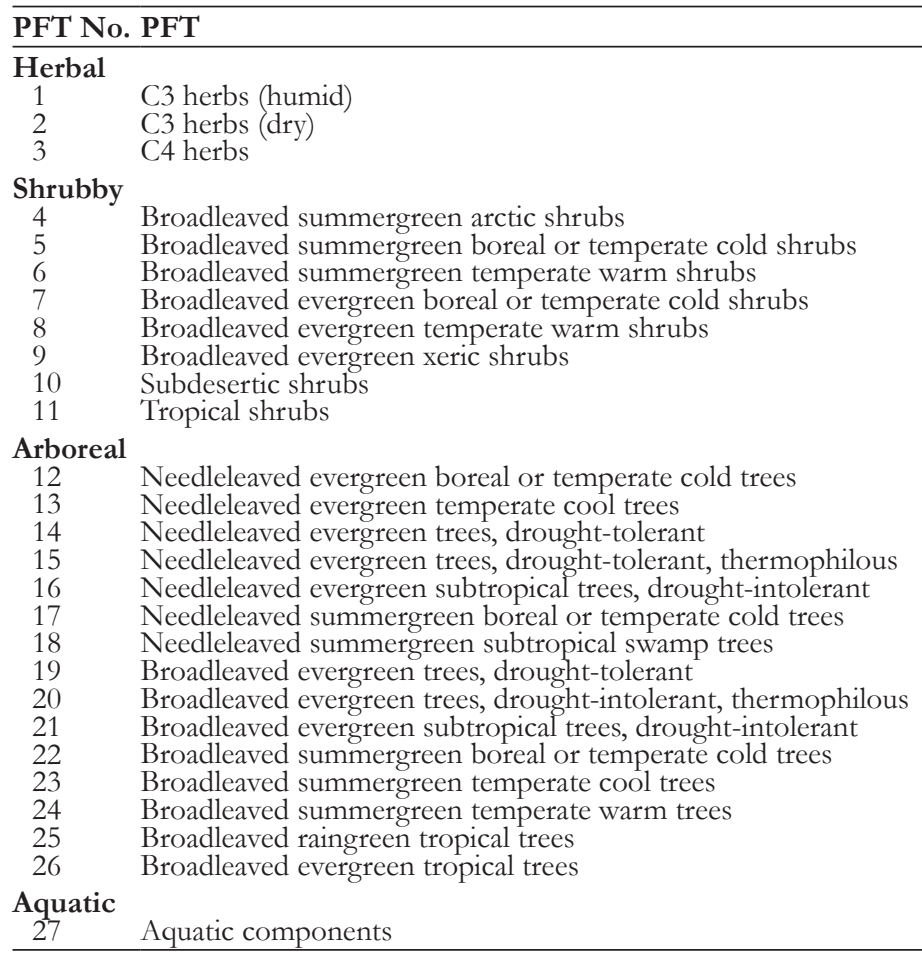

described in Utescher \& Mosbrugger (2007) and Utescher et al. (2007). Proportions of the different groups of PFTs are given in Table 4.

To exclude unlikely PFTs we use the likelihood procedure according to François et al. (2011) and Henrot et al.
(2017). This methodology is similar to the CA used in palaeoclimate reconstructions from the palaeobotanical records. In cases when several classes of arboreal PFTs are possible for a taxon, only those that can coexist with the other classes identified at the site are retained. It narrows the range of plant types present at the site by suppressing extreme end members, such as cold boreal/temperate and tropical PFTs. The coexistence table is then used to evaluate the likelihood for the presence of each PFT at each site, according to the four following affinity levels of coexistence: $\mathrm{H}$ - high, $\mathrm{M}$ - moderate, $\mathrm{L}$ - low, and I - improbable. Finally, all PFTs of low and improbable levels of coexistence were excluded from the analysis (Supplementary electronic information 2).

The PFT approach requires only information on presence and absence of taxa and thus is comparatively robust towards taphonomic bias. The approach can be applied on all types of fossil floras providing an adequate size of the sample.

\section{Plant biome reconstruction: Integrated Plant Record (IPR) vegetation analysis}

The Integrated Plant Record (IPR) vegetation analysis is a semi-quantitative method first introduced by Kovar-Eder \& Kvaček (2003) to assess zonal vegetation based on the fossil plant record (leaf, fruit, and pollen assemblages). In order to employ the IPR, 13 basic taxonomic-physiognomic groups, termed components, defined to reflect key ecological characteristics of an assemblage (Kovar-Eder \& Kvaček 2003, 2007, Kovar-Eder et al. 2008, Teodoridis et

Table 4. Proportions of the different groups of PFTs for each depth level. References and complete flora lists including Nearest Living Relatives used for vegetation analysis are given in Supplementary electronic information 2.

\begin{tabular}{|c|c|c|c|c|c|c|c|c|c|c|c|c|}
\hline \multirow{2}{*}{$\begin{array}{l}\text { Depth, } \\
\text { m }\end{array}$} & \multirow[t]{2}{*}{ Flora } & \multirow{2}{*}{$\begin{array}{l}\text { Number } \\
\text { of fossil } \\
\text { taxa allo- } \\
\text { cated to } \\
\text { PFTs }\end{array}$} & \multirow{2}{*}{$\begin{array}{l}\text { Number } \\
\text { of scores } \\
\text { before } \\
\text { likelihood } \\
\text { procedure }\end{array}$} & \multirow{2}{*}{$\begin{array}{l}\text { Number } \\
\text { of scores } \\
\text { after } \\
\text { likelihood } \\
\text { procedure }\end{array}$} & \multicolumn{8}{|c|}{ Plant functional types } \\
\hline & & & & & $\begin{array}{l}\text { Aquatic } \\
\text { (PFT 27) }\end{array}$ & $\begin{array}{c}\text { Terrest- } \\
\text { rial } \\
(1-26)\end{array}$ & $\begin{array}{c}\text { Herba- } \\
\text { ceous } \\
(1-3)\end{array}$ & $\begin{array}{c}\text { Shrubby } \\
(4-11)\end{array}$ & $\begin{array}{c}\text { Arboreal } \\
(12-26)\end{array}$ & $\begin{array}{l}\text { Coni- } \\
\text { ferous } \\
(12-18)\end{array}$ & $\begin{array}{c}\text { Deci- } \\
\text { duous (4- } \\
6,22-25)\end{array}$ & $\begin{array}{c}\text { Ever- } \\
\text { green }(7- \\
9,19-21, \\
26)\end{array}$ \\
\hline \multicolumn{13}{|c|}{ Late Paleocene } \\
\hline $\begin{array}{l}130.2 \\
133.0 \\
136.6 \\
138.2 \\
138.6 \\
140.2 \\
142.2 \\
143.3 \\
146.4 \\
150.5 \\
151.4\end{array}$ & $\begin{array}{l}\text { PF } 1 \\
\text { PF } 2 \\
\text { PF } 3 \\
\text { PF } 4 \\
\text { PF } 5 \\
\text { PF } 6 \\
\text { PF } 7 \\
\text { PF } 8 \\
\text { PF } 9 \\
\text { PF } 10 \\
\text { PF } 11\end{array}$ & $\begin{array}{l}18 \\
31 \\
34 \\
37 \\
33 \\
39 \\
39 \\
35 \\
27 \\
21 \\
37\end{array}$ & $\begin{array}{r}48 \\
112 \\
104 \\
119 \\
104 \\
121 \\
112 \\
95 \\
91 \\
74 \\
102\end{array}$ & $\begin{array}{l}40 \\
96 \\
77 \\
88 \\
75 \\
99 \\
83 \\
72 \\
67 \\
59 \\
77\end{array}$ & $\begin{array}{l}2.4 \\
2.1 \\
2.6 \\
3.4 \\
4.0 \\
4.0 \\
4.8 \\
4.2 \\
3.0 \\
5.1 \\
3.9\end{array}$ & $\begin{array}{l}97.6 \\
97.9 \\
97.4 \\
96.6 \\
96.0 \\
96.0 \\
95.2 \\
95.8 \\
97.0 \\
94.9 \\
96.1\end{array}$ & $\begin{array}{r}4.9 \\
3.1 \\
3.9 \\
8.0 \\
6.7 \\
6.1 \\
4.8 \\
11.1 \\
3.0 \\
1.7 \\
6.5\end{array}$ & $\begin{array}{l}26.8 \\
27.1 \\
23.4 \\
28.4 \\
25.3 \\
27.3 \\
22.9 \\
30.6 \\
29.9 \\
28.8 \\
23.4\end{array}$ & $\begin{array}{l}65.9 \\
67.7 \\
70.1 \\
60.2 \\
64.0 \\
62.6 \\
67.5 \\
54.2 \\
64.2 \\
64.4 \\
66.2\end{array}$ & $\begin{array}{r}29.3 \\
11.5 \\
15.6 \\
6.8 \\
8.0 \\
8.1 \\
20.5 \\
6.9 \\
4.5 \\
3.4 \\
22.1\end{array}$ & $\begin{array}{l}53.7 \\
46.9 \\
29.9 \\
36.4 \\
36.0 \\
52.5 \\
33.7 \\
38.9 \\
44.8 \\
35.6 \\
31.2\end{array}$ & $\begin{array}{r}7.3 \\
32.3 \\
45.5 \\
43.2 \\
44.0 \\
26.3 \\
33.7 \\
36.1 \\
41.8 \\
50.8 \\
32.5\end{array}$ \\
\hline \multicolumn{13}{|c|}{ Early Paleocene } \\
\hline $\begin{array}{l}152.6 \\
161.2 \\
170.0 \\
172.6 \\
174.3 \\
179.4 \\
180.2 \\
181.2 \\
183.1 \\
183.5 \\
185.5 \\
188.3 \\
207.4 \\
220.1 \\
\end{array}$ & $\begin{array}{l}\text { PF } 12 \\
\text { PF } 13 \\
\text { PF } 14 \\
\text { PF 15 } \\
\text { PF 16 } \\
\text { PF 17 } \\
\text { PF } 18 \\
\text { PF } 19 \\
\text { PF } 20 \\
\text { PF 21 } \\
\text { PF 22 } \\
\text { PF 23 } \\
\text { PF 24 } \\
\text { PF 25 }\end{array}$ & $\begin{array}{l}34 \\
26 \\
24 \\
27 \\
25 \\
30 \\
19 \\
22 \\
18 \\
28 \\
25 \\
26 \\
25 \\
29 \\
\end{array}$ & $\begin{array}{r}108 \\
86 \\
78 \\
76 \\
77 \\
100 \\
57 \\
76 \\
51 \\
79 \\
81 \\
79 \\
78 \\
97 \\
\end{array}$ & $\begin{array}{l}84 \\
65 \\
57 \\
57 \\
66 \\
71 \\
42 \\
58 \\
44 \\
61 \\
67 \\
55 \\
60 \\
72 \\
\end{array}$ & $\begin{array}{l}2.4 \\
3.1 \\
1.8 \\
1.8 \\
1.5 \\
0 \\
0 \\
0 \\
2.3 \\
1.6 \\
1.5 \\
1.8 \\
0 \\
0 \\
\end{array}$ & $\begin{array}{r}97.6 \\
96.9 \\
98.2 \\
98.2 \\
98.5 \\
100 \\
100 \\
100 \\
97.7 \\
98.4 \\
98.5 \\
98.2 \\
100 \\
100 \\
\end{array}$ & $\begin{array}{r}7.1 \\
4.6 \\
8.8 \\
15.8 \\
4.5 \\
8.5 \\
9.5 \\
3.4 \\
11.4 \\
9.8 \\
4.5 \\
7.3 \\
1.7 \\
5.6 \\
\end{array}$ & $\begin{array}{l}32.1 \\
24.6 \\
24.6 \\
14.0 \\
19.7 \\
25.4 \\
28.6 \\
32.8 \\
20.5 \\
31.1 \\
41.8 \\
27.3 \\
25.0 \\
33.3 \\
\end{array}$ & $\begin{array}{l}58.3 \\
67.7 \\
64.9 \\
68.4 \\
74.2 \\
66.2 \\
61.9 \\
63.8 \\
65.9 \\
57.4 \\
52.2 \\
63.6 \\
73.3 \\
61.1 \\
\end{array}$ & $\begin{array}{l}10.7 \\
13.8 \\
28.1 \\
28.1 \\
36.4 \\
25.4 \\
33.3 \\
29.3 \\
45.5 \\
23.0 \\
23.9 \\
38.2 \\
26.7 \\
20.8 \\
\end{array}$ & $\begin{array}{l}39.3 \\
33.8 \\
29.8 \\
22.8 \\
30.3 \\
33.8 \\
26.2 \\
31.0 \\
34.1 \\
36.1 \\
35.8 \\
38.2 \\
31.7 \\
40.3 \\
\end{array}$ & $\begin{array}{r}36.9 \\
41.5 \\
29.8 \\
28.1 \\
24.2 \\
29.6 \\
26.2 \\
31.0 \\
4.5 \\
24.6 \\
26.9 \\
12.7 \\
35.0 \\
29.2 \\
\end{array}$ \\
\hline
\end{tabular}


al. 2011) are used: conifer (CONIF), broadleaved deciduous (BLD), broadleaved evergreen (BLE), sclerophyllous (SCL), legume-like (LEG), zonal palm component (ZONPALM), arborescent fern (ARBFERN), dry herbaceous (D-HERB), mesophytic herbaceous (M-HERB). Azonal components, i.e. azonal woody component (AZW), azonal non-woody component (AZNW) and aquatic component (AQUA). The component PROBLEMATIC TAXA includes elements with uncertain taxonomic-physiognomic affinity. For further analysis, all taxa (but not their abundances) of every single assemblage have to be assigned to those components and their relative proportions have to be calculated. The complete flora lists, assigned NLRs and their allocation to the components are given in Supplementary electronic information 3. The number of taxa assigned to the components for each flora is given in Table 5.

To characterize zonal vegetation, the following proportions of components are regarded as relevant: (a) the proportion of the BLD, BLE, and SCL+LEG components of zonal woody angiosperms, where "zonal woody angiosperms" means sum of $\mathrm{BLD}+\mathrm{BLE}+\mathrm{SCL}+\mathrm{LEG}+\mathrm{ZONPALM}$ + ARBFERN components; (b) the proportion of the ZONAL HERB (D-HERB+M-HERB) component of all zonal taxa, where "zonal taxa" means sum of the $\mathrm{CONIF}+\mathrm{BLD}+\mathrm{B}$ $\mathrm{LE}+\mathrm{SCL}+\mathrm{LEG}+\mathrm{ZONPALM}+\mathrm{ARB}$ FERN+D-HERB+M-HERB components. The reliability of the results increases with increasing number of zonal taxa preserved. Ten zonal taxa are regarded as a minimum to perform this method (Kovar-Eder et al. 2008). Recently, Kovar-Eder \& Teodoridis (2018) raised the former threshold to 15 zonal taxa for the application of the IPR-vegetation analysis. The proportions of the components were calculated for each flora and are given in Table 5.

Based on relative proportions of the components the following six zonal vegetation types are distinguished (Kovar-Eder \& Kvaček 2007, Kovar-Eder et al. 2008): zonal temperate to warm temperate broadleaved deciduous forests (broadleaved deciduous forests,

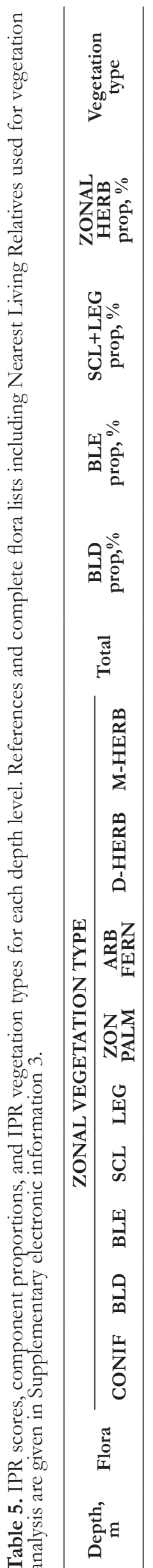

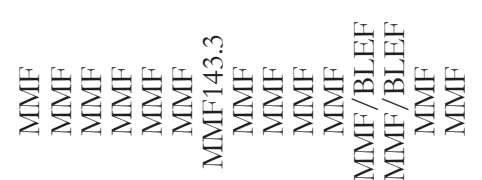

onnmomm

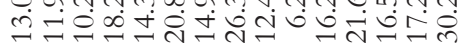

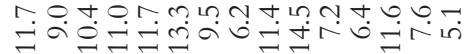

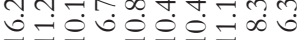

omn m thtommonam

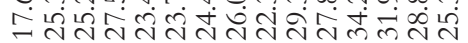

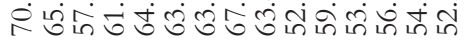

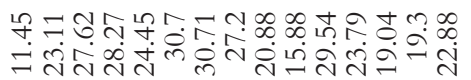

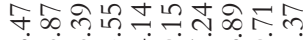

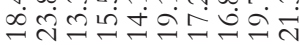

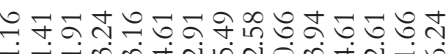

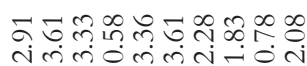

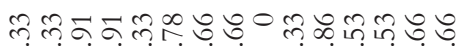

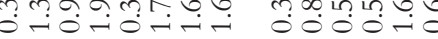

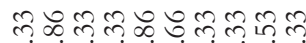

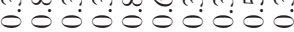

o0ro000000r-10rn

0000000000

00 n? 000 mon

0000000000

$00000-000-00000$

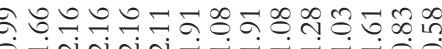

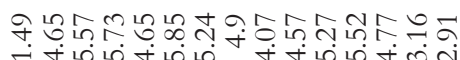

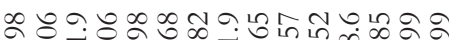

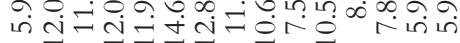

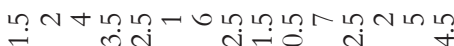

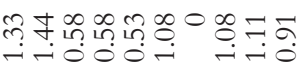

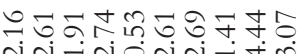

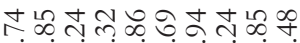

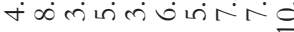

N 2 ?

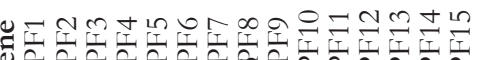

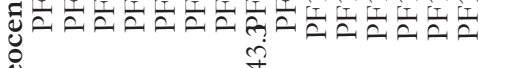

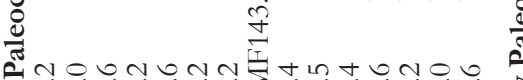

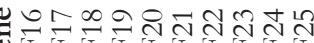

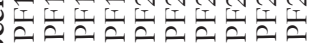
$\frac{\pi}{e^{2}}$

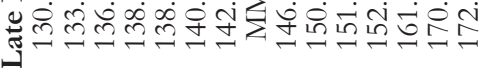


BLDF), zonal warm temperate to subtropical mixed mesophytic forests (mixed mesophytic forests, MMF), zonal subtropical broadleaved evergreen forests (broadleaved evergreen forests, BLEF), zonal subtropical, subhumid sclerophyllous or microphyllous forests (subhumid sclerophyllous forests, ShSF), zonal xeric open woodlands (open woodland), and zonal xeric grasslands or steppe (xeric grassland). Teodoridis et al. (2011) additionally defined ecotones between the BLDF and MMF and the BLEF and MMF and recently, Kovar-Eder \& Teodoridis (2018) defined ecotone between the MMF/ShSF.

\section{RESULTS}

\section{Palynological data}

Based on the works of Kezina (2005) and Kezina \& Litvinenko (2007), 90 taxa in total (56 angiosperms, 16 gymnosperms and 18 pteridophytes) were identified. Most taxa belong to groups which nowadays comprise trees and shrubs. Sporomorphs deriving from herbs were generally rare. Cluster analysis performed with the TILIA software yields 4 palynozones (Fig. 4).

Zone I ranges from 220 to $187 \mathrm{~m}$ in depth (Fig. 4). Angiosperm pollen dominates (up to $75.8 \%$ ), with mostly Myrica sp., Corylopsis sp., Comptonia sp., Triporopollenites plectosus And., Triatriopollenites sp., and Triporopollenites sp. Gymnosperm taxa account for up to $32.5 \%$, dominated by Cupressaceae Gray and Pinaceae Lindl. Pteridophytes are relatively rare (4.7 to $11.9 \%$ ), and are mainly represented by Polypodiaceae Bercht. et J. Presl.

Zone II ranges from 187 to $174 \mathrm{~m}$ in depth (Fig. 4). Gymnosperms (29.7 to $62.4 \%$ ) and Pteridophytes (10.0 to $55.1 \%$ alternately dominate the assemblages. The gymnosperms are dominated by Taxodioideae (including Taxodium) - up to $65 \%$. Pteridophytes represented by Polypodiaceae (up to $40.6 \%$ ) and Onoclea (up to $14.0 \%$ ) spores. Angiosperm palynomorphs (up to $27.6 \%$ ) occur at a lower frequency than in Zone I, and include abundant Alnus sp., Myrica sp., Cuprianipillis sp., Sparganium sp. and Triporopollenites plectosus.

Zone III ranges from 174 to $153 \mathrm{~m}$ in depth (Fig. 4). Angiosperm pollen dominates and reaches $92.7 \%$. Angiosperms are represented mainly by Ulmoideipites tricostatus And. (up to $71.2 \%$ ) and Sparganium sp. (up to $23.9 \%$ ). Pteridophytes (up to $35.3 \%$ ) are dominated by Onoclea sp. (up to $23.9 \%$ ) and Polypodiaceae (up to $15.4 \%$ ). Gymnosperm taxa occur at a lower frequency (4.0 to $13.7 \%$ ).

Zone IV ranges from 153 to $130 \mathrm{~m}$ in depth (Fig. 4). Angiosperm pollen predominates (48.1 to $94.0 \%$ ) with mostly Triporopollenites plectosus, Myrica sp., Moraceae Link, Pandanus sp., Platycarya sp., Anacolosidites sp., Fagaceae Dumort. (including Quercus gracilis Boitz. and Quercus sp.), Hamamelidaceae R. Brown. Corylopsis pollen is very frequent $(53.2 \%)$ in topmost part of this zone, with a relatively low proportion of Fothergilla sp. (0.9 \%). Gymnosperms (0.9 to $41.8 \%$ ) and Pteridophytes (2.0 to $46.2 \%$ ) alternately dominate the assemblages. The Gymnosperm taxa are dominated by Taxodioideae (up to $41.8 \%$ from a depth of $136.6 \mathrm{~cm}$ ). Azolla sp. (up to $24.7 \%$ ) and Salvinia sp. (up to $18.3 \%$ ) are dominate among Pteridophytes in the lower part of this zone.

\section{Paleoclimate reconstruction}

The analysis of 25 microfloras is based on 16 to 36 (mean 26.24) climate datasets of extant reference taxa. In 25 out of 14 cases, all NLRs can coexist, in all other cases over $99 \%$ of taxa attributing high significance. When reconstructing CA intervals of the MAT obtained from the microfloras $\mathrm{CA}$ ranges are comparatively wide owing to the commonly high taxonomic level of NLR assignment. For MAT the width of $\mathrm{CA}$ intervals is $\mathrm{ca} .8 .4^{\circ} \mathrm{C}$ at the mean (varies from $6.1^{\circ} \mathrm{C}$ to $10.6^{\circ} \mathrm{C}$ ).

The mean values of MAT show a general smooth cooling trend in the lower part and warming trend in upper part of the well (Table 1, Fig. 5). The highest MAT values are indicated in the early Paleocene for the PF 24 at $207.4 \mathrm{~m}-$ $18.4^{\circ} \mathrm{C}\left(15.3-21.4^{\circ} \mathrm{C}\right)$, in the late Paleocene for five floras at $138.2-138.6 \mathrm{~m}$ and $143.3-150.5 \mathrm{~m}-19.0^{\circ} \mathrm{C}\left(14.8-23.1^{\circ} \mathrm{C}\right)$. The lowest MAT values are indicated in the early Paleocene for the PF $23-16.4^{\circ} \mathrm{C}\left(11.1-21.7^{\circ} \mathrm{C}\right)$, in the late Paleocene for the PF 4 and PF 14 and $15-17.0^{\circ} \mathrm{C}\left(12.6-21.4^{\circ} \mathrm{C}\right)$. For the other floras of the early Paleocene the MAT mean values vary in the range of $16.5-17.2^{\circ} \mathrm{C}$, while of the late Paleocene - from 17.8 to $18.5^{\circ} \mathrm{C}$.

For the CMMT means demonstrate a general warming trend throughout the Paleocene (Table 1, Fig. 5). The highest values of CMMT are indicated in the early Paleocene for the PF $23-11.1^{\circ} \mathrm{C}\left(6.6-15.6^{\circ} \mathrm{C}\right)$ and in the late Paleocene for the PF 5 and $9-11.8^{\circ} \mathrm{C}\left(6.6-17.0^{\circ} \mathrm{C}\right)$. The lowest CMMT values are obtained in the early Paleocene for the PF 22 and $25-6.8^{\circ} \mathrm{C}\left(-0.3-13.9^{\circ} \mathrm{C}\right)$, in the late Paleocene for the PF $15-10.2^{\circ} \mathrm{C}\left(6.4-13.9^{\circ} \mathrm{C}\right)$. For the other floras of the early Paleocene the mean values of MAT vary from 7.5 to $10.3^{\circ} \mathrm{C}$, of the late Paleocene - from 10.3 to $11.7^{\circ} \mathrm{C}$.

WMMT means vary slightly during the Paleocene (Table 1 , Fig. 5). The highest WMMT values are indicated in the early Paleocene for the PF $25-25.7^{\circ} \mathrm{C}\left(23.0-28.3^{\circ} \mathrm{C}\right)$, while in the late Paleocene for the PF $1-26.0^{\circ} \mathrm{C}\left(23.6-28.4^{\circ} \mathrm{C}\right)$. The lowest values of WMMT are obtained in the early Paleocene for the PF $16-23.8^{\circ} \mathrm{C}\left(19.4-28.1^{\circ} \mathrm{C}\right)$, in the late Paleocene for the PF $15-24.2^{\circ} \mathrm{C}\left(20.2-28.1^{\circ} \mathrm{C}\right)$. For the other floras of the early Paleocene the mean values of WMMT vary from 24.9 to $25.6^{\circ} \mathrm{C}$, of the late Paleocene - from 25.2 to $25.7^{\circ} \mathrm{C}$.

MAP shows a general decrease from $1200-1350 \mathrm{~mm}$ in the lower part of the early Paleocene to 1100-1200 mm in the upper part of the early Paleocene (Table 1, Fig. 5). The highest Paleocene values of MAP are indicated in the early Paleocene for the PF $18-1659 \mathrm{~mm}(703-2615 \mathrm{~mm})$ and in the late Paleocene for the PF 10 - $1740 \mathrm{~mm}(979-2500 \mathrm{~mm})$. Other floras indicate a MAP of at least $1200 \mathrm{~mm}$.

MPdry means in the Paleogene of the Amur Region were at ca. 27-53 mm (Table 1, Fig. 5).

The mean values of MPwet attain very high values (177-270 mm) throughout the Paleocene (Table 1, Fig. 5).

\section{Climate seasonality, monsoon intensity}

Temperature (MART) and precipitation (MARP) seasonality parameters and the mean values of related climatic parameters for each flora are given in Table 2 in comparison to the present-day values. The MART ranges in 13.5$18.9^{\circ} \mathrm{C}$ in the early Paleocene and up to $15.4^{\circ} \mathrm{C}$ in the late 

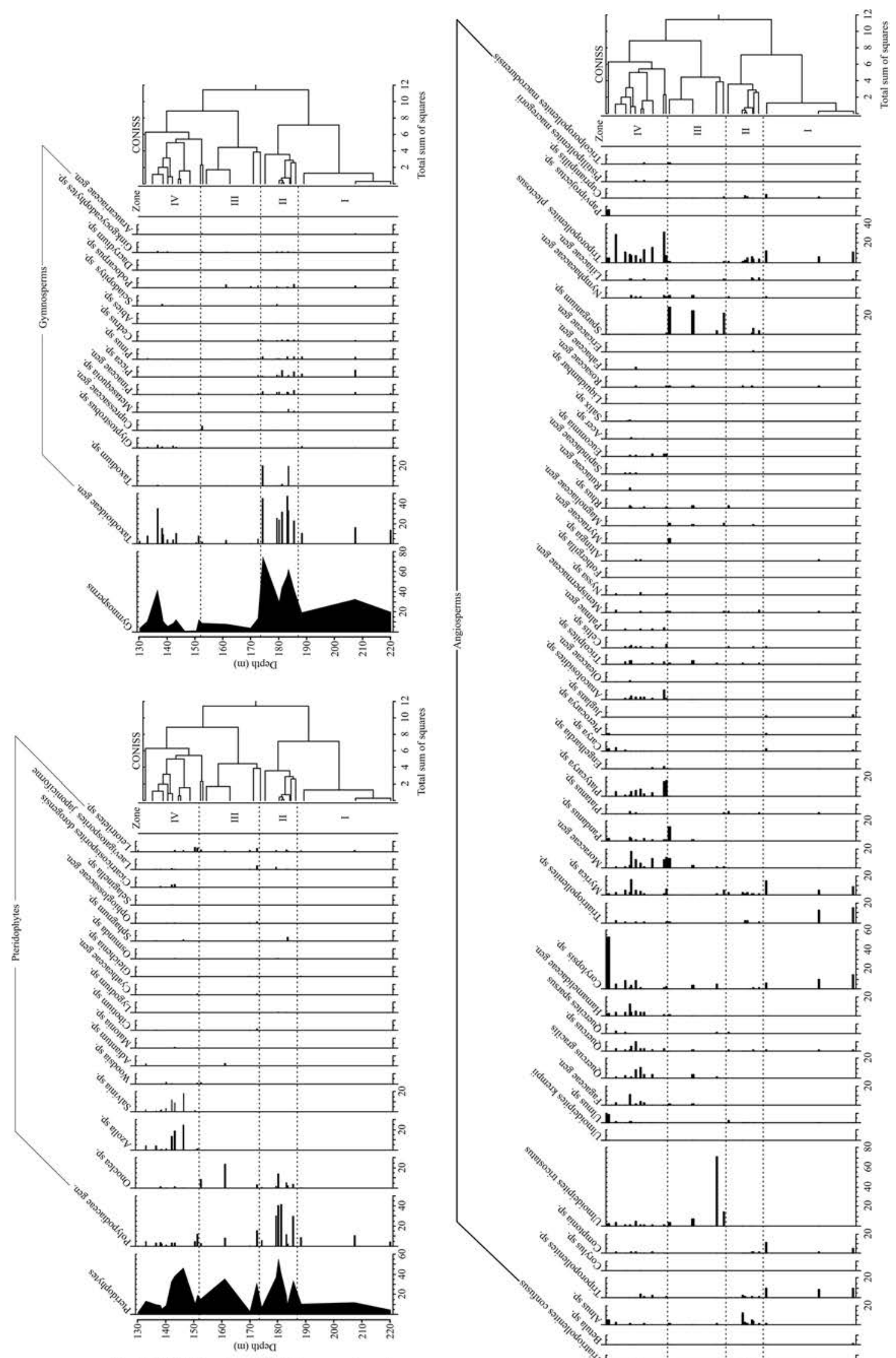

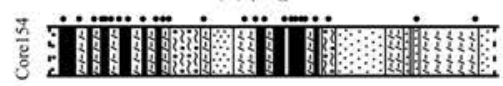
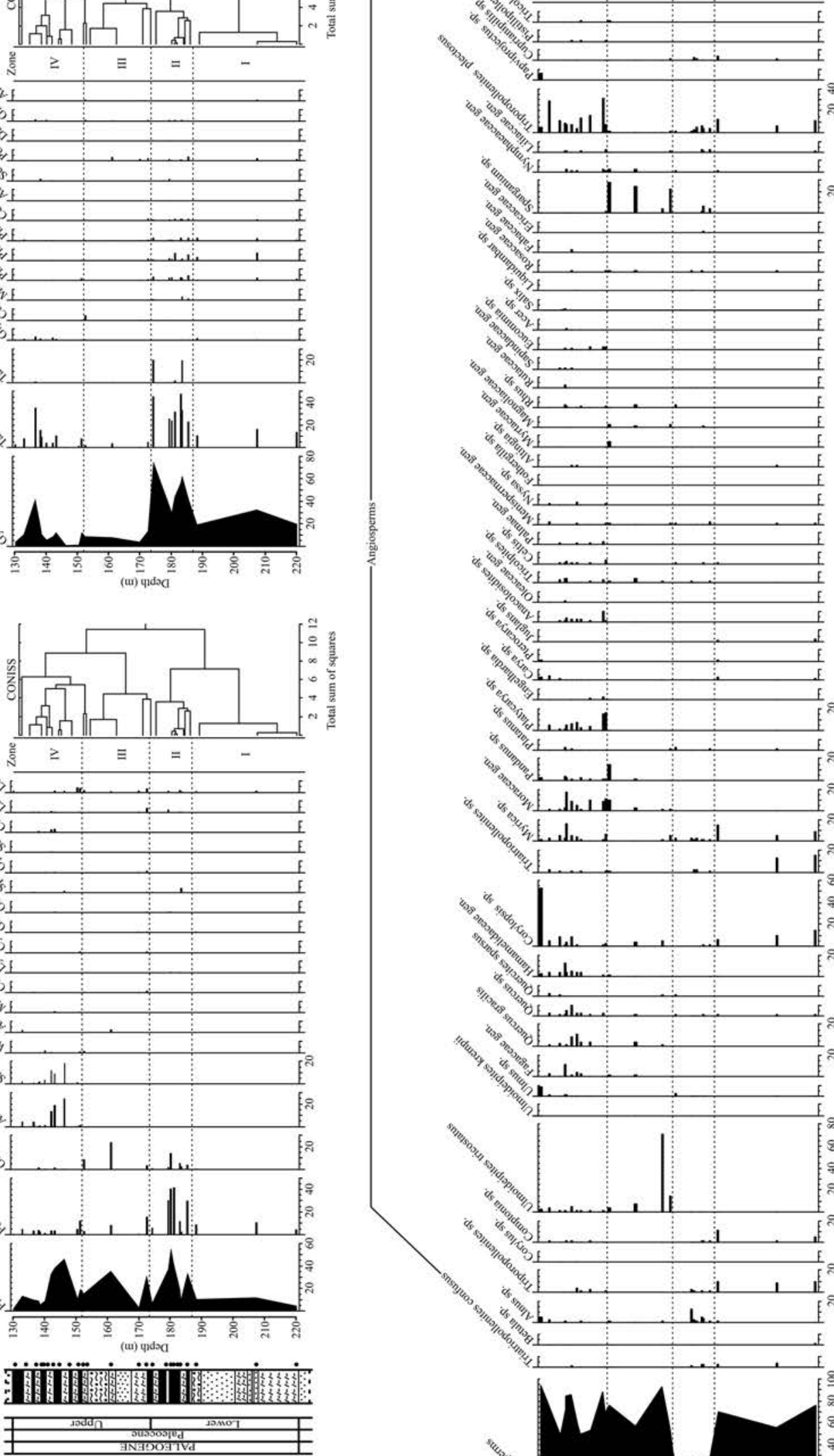

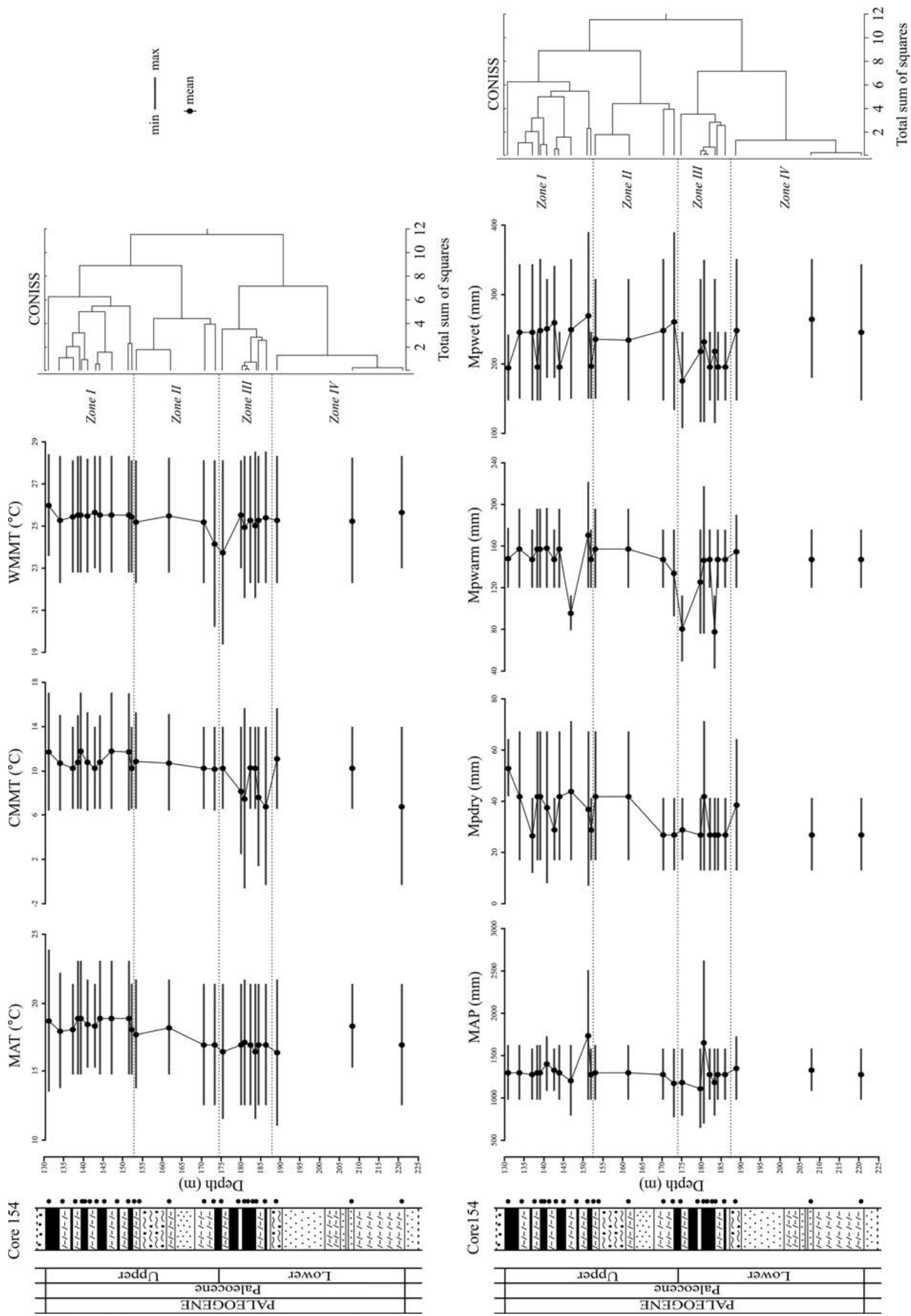

Figure 5 Temperature and precipitation variables: MAT - mean annual temperature, CMMT - cold month mean temperature, WMMT - warm month mean temperature, MAP - mean annual precipitation, MPwet - mean monthly precipitation of the wettest month, MPdry - mean monthly precipitation of the driest month, MPwarm - mean monthly precipitation of the warmest month 
Paleocene. The MARP varies from 148 to $238 \mathrm{~mm}$ in the early Paleocene and from 142 to $235 \mathrm{~mm}$ in the late Paleocene. The RMPwet fluctuates within 14.0-20.4\% in the early Paleocene and from 15.0 to $22.3 \%$ in the late Paleocene, while the RMPdry varied from 2.0 to $2.9 \%$ in the early Paleocene and from 2.1 to $4.1 \%$ in the late Paleocene (Table 2).

\section{Vegetation: PFT approach}

Using the PFT approach, palaeovegetation data of the Amur Region were obtained for 25 palynofloras. The number of fossil taxa in each sample is lower than the number of encountered PFTs (Table 4), therefore we consider that our results are meaningful. Aquatic plants (PFT 27) are presented in 20 palynofloras. The proportion of aquatic plants varies from 0 to $2.3 \%$ in the early Paleocene and from 1.8 to $4.6 \%$ in the late Paleocene (Table 4, Fig. 6). Herbaceous plants (PFTs 1-3) are presented in all floras. The diversity of herbaceous PFTs varies from 1.7 to $11.4 \%$ of total diversity of the flora in the early Paleocene and from 1.5 to $15.8 \%$ in the late Paleocene (Table 4, Fig. 6 and 7). Shrubs (PFTs 4-11) are presented in all floras studied: 19.7-41.8 and $14.03-32.9 \%$ in the early and late Paleocene correspondently (Table 4, Fig. 6). After applying the likelihood procedure, arboreal plants (PFTs 12-26) are presented in all floras studied. Arboreal PFTs content 52.2-74.2 in the early Paleocene floras and 53.9-68.4\% in the late Paleocene floras (Table 4, Fig. 6 and 7). Needleleaved (PFTs 12-18) are presented in all floras. In the early Paleocene floras the proportion of coniferous varies within the range of 20.8$45.5 \%$, in the late Paleocene floras $-3.1-29.3 \%$ of total diversity of the flora (Table 4, Fig. 6 and 7). Broadleaved deciduous plants (PFTs 4-6, 22-25) are present in all floras. The diversity of deciduous PFTs in the early Paleocene varies from 26.2 to $40.3 \%$, in the late Paleocene floras from 22.8 to $53.7 \%$ of total diversity of the flora (Table 4 ). Broadleaved evergreens (PFTs 7-9, 19-21, 26) are present in all floras. The proportion of broadleaved evergreens varies from 4.5 to $35.0 \%$ in the early Paleocene floras and from 7.3 to $52.3 \%$ of total diversity of the flora in the late Paleocene floras (Table 4, Fig. 6 and 7).

When regarding the diversity spectra of the Paleocene floras analyzed (Fig. 6), it is shown that broadleaved summergreen shrubs and trees (PFTs 5, 6, and 24) are the most important functional types, followed by broadleaved evergreen shrubs and trees (PFTs 8/9 and 19-21) and needleleaved evergreens (PFTs 13-16 and 18). Needleleaved summergreen boreal trees (PFT 17) and needleleaved evergreen boreal or temperate cold trees (PFT 12) are completely absent in the spectra after the likelihood procedure. Needleleaved summergreen subtropical swamp trees (PFT 18) are presented in all floras (Fig. 6). Herbaceous plants in the Paleocene floras of the Amur Region are mainly represented by humid herbs (PFT 1).

In general, the diversity spectra of the floras are characterized by high diversities of broadleaved summergreen (22.8-52.5\%), broadleaved evergreen (12.7-50.8\%) and needleleaved PFTs (3.4-36.4\%), with the exception of PF 1 characterized by highest diversities of broadleaved summergreen $(53.7 \%)$ and very low diversities of evergreen PFTs
(7.3\%) and PF 20 characterized by highest diversities of needleleaved $(45.5 \%)$ and lowest diversities of broadleaved evergreen PFTs $(4.5 \%)$.

\section{IPR vegetation analysis}

To apply IPR-vegetation analysis, 25 microfloras were analyzed. Based on the relative proportions of the components, one zonal vegetation type and two ecotones between them were revealed for the Paleocene of the Amur Region (Table 5, Fig. 6 and 7). The zonal vegetation type of warm temperate to subtropical mixed mesophytic forest (= mixed mesophytic forest, MMF) was revealed for most floras (18 out of 25), but mainly (12 floras) in the late Paleocene. The floras assigned to this zonal vegetation type are characterized by proportions of the BLD component from 52 to $74 \%$, BLE component - 14-30\%, SCL+LEG component - 5-16 \%, and 10-30\% of herbs. The ecotones (MMF/ BLEF and BLDF/MMF) are characterized by the transitional (intermediate) proportions of components in comparison with the corresponding zonal vegetation types (Table 5, Fig. 6 and 7). The ecotone MMF/BLEF was revealed for floras (6 out of 25) in the Early Paleocene and is characterized by $51-62 \%$ of BLD, 31-34 \% of BLE, $6-14 \%$ of SCL+LEG, and 6-22\% of herbs. The ecotone BLDF/ MMF was revealed only for the flora (PF 20) at the level $183.1 \mathrm{~m}$ in the Early Paleocene and is characterized by $78 \%$ of BLD, $11 \%$ of BLE, $11 \%$ of SCL+LEG, and $30 \%$ of herbaceous components.

\section{DISCUSSION \\ Paleocene climate evolution}

For all known uncertainties and delimited climatic resolution primarily caused by uncertainties in NLR identification and their high taxonomical rank basic conclusions on the Paleocene climate of the mid-latitudinal Amur Region can be drawn. Given the scarcity of continental quantitative palaeoclimate data for the Paleocene in general, also rough estimated may provide valuable information. With MAT of at least ca. $15^{\circ} \mathrm{C}$ and $\mathrm{CMMT}$ ca. $6^{\circ} \mathrm{C}$ in the warmer parts of the record and ca. $12.5^{\circ} \mathrm{C} / 0^{\circ} \mathrm{C}$ in the coolest part, a warm temperate or possibly also nearly cool temperate climate persisted throughout the deposition of the strata. The climate was overall humid, with high MAP rates of at least ca. $1000 \mathrm{~mm}$ in the warmer phases and over ca. $750 \mathrm{~mm}$ during the cooler phases. The above lower limits coincide with most results obtained from coeval macroand microfloras in the coastal area of neighboring Primorye (Bondarenko et al. 2019), except for the early Paleocene Ustinovka leaf flora indicating somewhat warmer conditions (MAT ca. $16-21^{\circ} \mathrm{C}$; CMT ca. $9-10{ }^{\circ} \mathrm{C}$ ). Further CA-based data come from several well-dated sites of NE China (e.g., Fushun Mine). These data tend to have somewhat warmer cool limits of CA intervals, with MATmin ca. $17-18^{\circ} \mathrm{C}$, and CMMTmin $>7^{\circ} \mathrm{C}$ (Quan et al. 2012b), possibly referable to a minor latitudinal gradient.

When assessing the Paleocene temperature level in respect to the early Paleogene evolution in general there is evidence for overall cooler conditions compared to the Eocene. A warming trend from the late Paleocene to the 


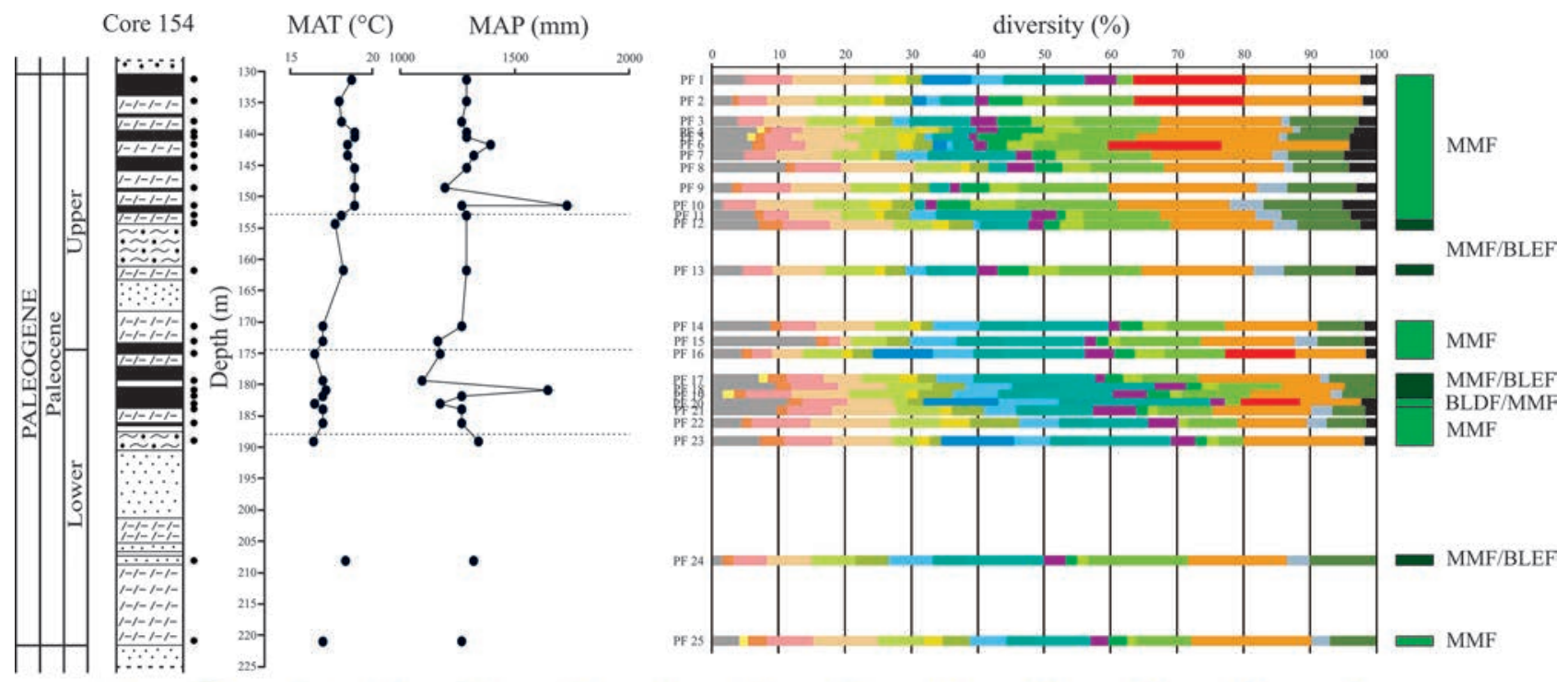

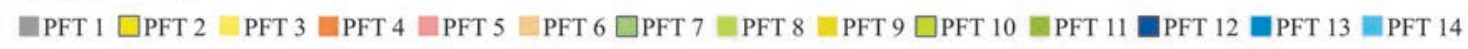

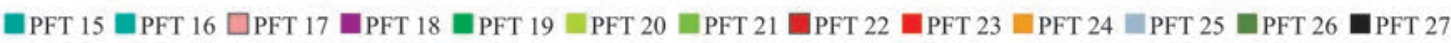

\section{present in the ecospectra \\ $\square$ absent from the ecospectra}

Figure 6 Ecospectra of PFT diversity and vegetation types next to lithological profile of the studied Core 154 and curves of MAT and MAP: MAT - mean annual temperature, MAP - mean annual precipitation, MMF - mixed mesophytic forest, MMF/BLEF - ecotone between mixed mesophytic forest and broadleaved evergreen forest, BLDF/MMF - ecotone between broadleaved deciduous forest and mixed mesophytic forest

early Eocene has been reported from various mid-latitudinal continental parts of the Northern Hemisphere such as Kazakhstan (Akhmetiev 2010), Bighorn Basin (Wilf 2000, Fricke \& Wing 2004), the NW German Cenozoic (Inglis et al. 2017). In North America and Europe, the early to middle Eocene warmth led to almost tropical climate conditions, with MATs well over $20^{\circ} \mathrm{C}$ in the mid-latitudes (e.g., Wilf 2000, Woodburne et al. 2009, Mosbrugger et al. 2005), partly exceeding the maximum values of $\mathrm{CA}$ intervals obtained in our reconstruction. For the mid-latitudes of East Asia, however, it has been suggested that the Eocene continental warmth was less pronounced (based on Chinese localities: MAT $<20^{\circ} \mathrm{C}$; CMMT $<12.5^{\circ} \mathrm{C}$ ) (Zhang et al. 2016), also data from Primorye point to a lower Eocene temperature level compared to the Atlantic Eurasian area at the same latitude (Utescher et al. 2015).

The above described Paleocene-Eocene continental warming trend coincides with the global marine isotope stack (Zachos et al. 2008) and is likewise mirrored in other marine proxies such as faunal patterns in Tethyan carbonate platforms (Scheibner \& Speijer 2008). Hence, this warming trend represents a global pattern that appears to be at odds with the generally declining atmospheric $\mathrm{CO}_{2}$ reported for that time-span (Zachos et al. 2008, Huber \& Caballero 2011). However, stomatal-based proxies suggest time intervals with $\mathrm{pCO}_{2}$ as low as 300 ppmv during the Paleocene (Beerling \& Royer 2011, Steinthorsdottir et al. 2016).

Apart from information on the general Paleocene temperature level in the study area our data provide the first more detailed time series possibly spanning most of the Paleocene. For the lower part of Core 154 only two productive samples are available and hence no clear temporal trends are revealed. However, from depth level $190 \mathrm{~m}$ upwards means of CA intervals obtained for MAT display a distinct overall warming trend coinciding with the declining trend in $\mathrm{d}^{18} \mathrm{O}$ values in the global isotope stack throughout the later Paleocene (Zachos et al. 2008). At the same time there is a trend to more equable climates as evident from declining MART (Fig. 3). In this context it is noteworthy that globally cooler conditions as evident from comparatively high $\mathrm{d}^{18} \mathrm{O}$ values near the $\mathrm{K}-\mathrm{T}$ boundary possibly correlate with the highest seasonality of temperature in our record (MART ca. $19^{\circ} \mathrm{C}$ at depth level $220 \mathrm{~m}$ ).

According to the palynostratigraphical constraints outlined in the next Section, this warming would comprise the late Danian to Thanetian while the warm peak in the Selandian would not be recorded in the continental data. Considering shorter-term variability our MAT record suggests an alternative stratigraphic solution in which the positive isotope shift in the earliest Thanetian correlates with a cool phase observed near the base of the lower brown coal unit in the core (at depth level $183 \mathrm{~m}$ ). Moreover, the intermittent cooling setting on at depth level $138 \mathrm{~m}$ might mirror the short-term cooling in the global isotope record pre-dating the PETM (Zachos et al. 2008).

As is shown in Fig. 3, our Paleocene data suggest a strong impact of climate change and variability on vegetation composition in the Amur Region. This is mainly evident from changes in the ratio of broadleaved evergreen versus deciduous PFTs that largely co-varies with MAT exemplifying the affinity of evergreens to warmer climates.

\section{Paleocene vegetation change: general aspects of the evolution of Paleocene palynomorph complexes in the Amur Region}

According to the data of Kezina (2005) and Kezina \& Litvinenko (2007), the prevalence of angiosperms (up to 

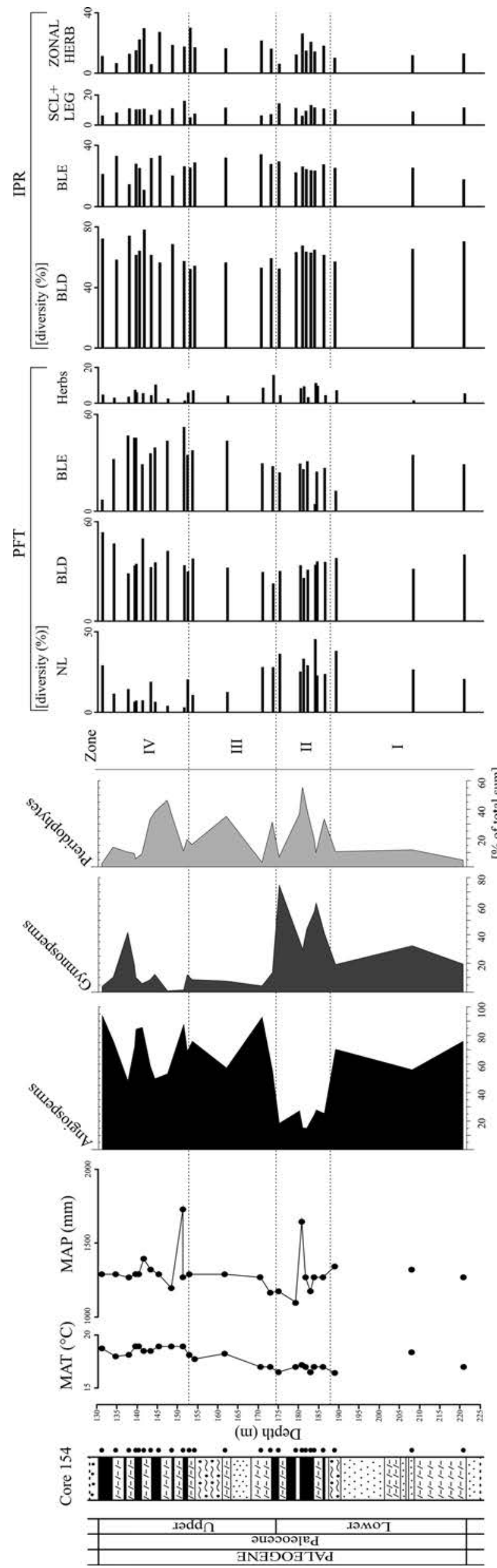

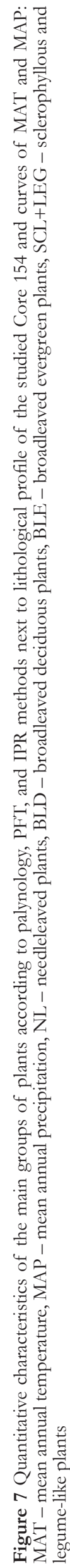

$60 \%$ is typical for the Middle Tsagayanskaya subformation, while the prevalence of spores and angiosperms is typical for the Upper Tsagayanskaya subformation. The Kivdinskie layers are characterized by the absolute dominance of Taxodioideae (up to 66-83\%). Based on formally estimating of variations in the record, our data suggest four zones differing in proportions of pteridophytes, gymnosperms and angiosperms. Thus, angiosperms prevail at depths from 220 to $187 \mathrm{~m}$, from 174 to $153 \mathrm{~m}$ and from 153 to $130 \mathrm{~m}$, while spore plants and gymnosperms dominated at depths from 187 to $174 \mathrm{~m}$. Taxodioideae prevail at depths from 153 to $130 \mathrm{~m}$. Ziva (1973) and Kezina (2005) placed the early/late Paleocene boundary at the level of $174 \mathrm{~m}$. Later, Kezina \& Litvinenko (2007) moved this boundary to $130 \mathrm{~m}$. According to our data, the early/late Paleocene (Danian/Selandian) boundary corresponds to the boundary between the Zones II and III at the level of $174 \mathrm{~m}$.

The prevalence of Ulmaceae pollen in the complex of the lower, predominantly sandy, part of the Upper Tsagayanskaya subformation, as well as the presence of Betulaceae Gray, Fagaceae, Hamamelidaceae, Juglandaceae A. Richard ex Kunth, and triporate morphotypes with unclear botanical affinity (Triporopollenites plicoides Zakl., Triatriopollenites confusus Zakl., Triatriopollenites sp., Tricolpites sp., Tricolporopollenites sp., etc.) with accessory Cretaceous relics (Parviprojectus sp., Anacolocidites sp., etc.), brings this complex closer to the Upper Tsagayanskaya complex of the Arkharo-Boguchanskii Brown Coal Field and the complex of the flora-bearing stratotypes of the Belaya Mountain (Kezina 2005, Kezina \& Litvinenko 2007). In terms of taxon composition, this palynocomplex is likewise close to the Danian palynocomplexes of the Zeisko-Bureinskii Basin (Khlonova 1969). Based on its characteristic taxonomic composition, namely the dominance of angiosperms with a variety of spores and a small number of gymnosperms, and presence of spores typical of the Late Cretaceous palynoflora this complex is also comparable with the early Paleocene palynocomplex of the Tsagayanskaya Formation (upper subformation) of the Ushumunskii (Mamontova 1975) and AmuroZeiskii Basins (Brattseva 1969). Moreover, this palynocomplex is similar to the late Maastrichtian and Danian complexes of marine and continental sediments of Sakhalin (Budrin \& Gromova 1973). A similar complex is described in Primorye (Markevich 1995), whose age is determined in the interval of late Maastrichtian - early Danian. In general, according to Kezina (2005), the palynocomplex characterizes the flora of the transitional interval, when individual Cretaceous relics were still present in the flora, but elements of the boreal flora (Betula L., Alnus Mill., Ericaceae, etc.), that later widely spread throughout the Cenozoic, already had appeared and diversified.

A similar composition of the palynocomplex of the coal-bearing part of the Upper Tsagayanskaya subformation (= Kivdinskie layers) has been established for 
other cores in the Erkovetskii Brown Coal Field (Mal'tseva \& Kezina 1985). The palynocomplex has a general systematic composition and an association of taxa (Ulmoideipites tricostatus, Quercites sparsus (Mart.) Samoil., Triatriopollenites confusus, Myrica sp., Comptonia sp., Pterocarya sp., etc.) considered characteristic of the "Kivdinskaya Formation" (Danian - Paleocene) as established by Brattseva (1969) for sections of the Raichikhinskii Brown Coal Field. However, the spectrum of the uppermost flora (PF 1) is somewhat different in composition from the rest of the floras (PFs 2-15) attributed to the Kivdinskie layers of the Upper Tsagayanskaya subformation by the appearance of Fothergilla sp. The same situation is reported by Kezina (2005) in the Raichikhinskii Brown Coal Field, where the spectrum of the uppermost flora from the Kivdinskie layers differs in composition from the underlying floras by the appearance of Fothergilla sp., Rhus sp., Araliaceae Juss., Ericaceae, and higher abundance of Betulaceae, etc. According to Kezina (2005), this is the evidence of the late Paleocene age close to the Eocene (e.g., end of the Thanetian). In addition, it should be noted that Fothergilla sp., along with others, is one of the leading taxa for Eocene sediments of Siberia (Kul'kova 1973) and the Far East (Brattseva 1969).

\section{Vegetation change}

Using PFT diversity spectra as proxies for vegetation type (Table 4, Fig. 6 and 7), the vegetation of the Amur Region in the Paleocene mainly was of mixed evergreen-deciduous type, except for the mixed deciduous-conifer forest with some evergreens at $130.2 \mathrm{~m}$ and the mixed conifer-deciduous forest with some evergreens at depth level $183.1 \mathrm{~m}$. The results obtained from the PFT approach are in accordance with our data obtained from IPR approach. Based on IPR, the MMF zonal vegetation type dominated in the Amur Region during the Paleocene, especially in the upper part. The warmest vegetation type, representing by the ecotone MMF/BLEF, was obtained in the lower part at depth levels 152.6-161.2, 180.2-181.2, and $207.4 \mathrm{~m}$. The coldest vegetation type, representing by the ecotone BLDF/MMF, was revealed only for the PF 20 at the $183.1 \mathrm{~m}$ (Table 5, Fig. 6 and 7). In both cases zonal forest biomes have a warm temperate character.

It is known that vegetation changes are often induced by climate change. The observed vegetation patterns and their changes through the Paleocene in many cases can be correlated with warm temperate climate patterns and the overall continental palaeoclimate evolution as reconstructed from the palaeobotanical record. The change in the proportion of some groups of PFTs (needleleaved vs. broadleaved, broadleaved deciduous vs. broadleaved evergreen) throughout the Paleocene also reflects changes in some climatic parameters (Fig. 3). The constant presence of PFT 18 in all studied floras throughout the Paleocene suggests a high humidity in general, and agrees with the precipitation reconstruction demonstrating considerably wetter conditions than at present. PFT 18 is also indicative for the existence of swamps at places and intrazonal swamp forest communities and thus points to the presence of inundated areas throughout the studied time-span. The constant presence of humid herbs (PFT 1) as well coincides with the mentioned above high humidity throughout the Paleocene.

The tropical PFTs (PFT 25 and 26) are present in many floras but in the low proportion (up to $11.9 \%, 1.9-6.3 \%$ at mean). Nevertheless, many taxa scoring for tropical PFTs may represent temperate types (for example, Hamamelidaceae, Magnoliaceae Juss., Minispermaceae Juss., Ulmaceae Mirb., etc.). However, the warmest IPR vegetation types are observed in the Danian part while PFT analysis point to higher broadleaved evergreen diversity in the upper part (which agrees with the inferred climate evolution).

There is evidence from our data that Paleocene mid-latitude vegetation of the Amur Region was basically warm temperate mixed forest. In contrast to the Amur Region, zonal temperate to warm temperate broadleaved deciduous forest (BLDF) was reconstructed for the Paleocene of Primorye using IPR (Bondarenko et al. 2019), and broadleaved deciduous forest was reconstructed based on PFT (Bondarenko et al. 2020a). Moreover, in the Paleogene of Primorye, all tropical PFTs are excluded when applying the likelihood procedure. The absence of tropical PFTs in the Paleocene of Primorye makes sense when considering the latitudinal position of the study area and the reconstructed palaeoclimate which does not support the occurrence of tropical plants (Bondarenko et al. 2020a), but it is in contrast with Bolotnikova (1979) and Lopatina (2004) suggesting the presence of tropical vegetation. There is evidence that in the RFE, thermophilous vegetation persisted even in the Neogene. From early Neogene carpofloras of the eastern RFE, Popova et al. (2013) reconstructed a high diversity $(40-50 \%)$ of warm temperate woody plants, including evergreen broadleaved trees.

In contrast to the Amur Region and Primorye, according to Collinson (1990, 2000, 2001), a thick tropical, subtropical and deciduous forest cover existed in the Paleocene around the globe. Graham (1999: 162-169) and Brea et al. (2011) indicated tropical and subtropical forests worldwide, mainly populated by conifers and broadleaved trees. Willis \& McElwain (2002) show that in the Paleocene even the Polar Regions were covered with coniferous and deciduous forests. In the North Dakota, floras include the same floral families have characterized South American rainforests and the American Western Interior since the Paleocene (Wing et al. 2009, Brea et al. 2011). Most likely, these differences can be explained by different approaches to the reconstruction of vegetation and interpretation of the results.

The middle part of the succession, from depth levels 187 to $174 \mathrm{~m}$ (Fig. 4), is characterized by high diversity of conifers, dominated by Taxodioideae. This phase correlates with an overall lower temperature level. Forests with high proportion of Taxodium refer to brown coal facies and may represent azonal vegetation connected to increased extension of peat bog facies.

Diversity evolution in our record testifies an already relatively high level for the earliest Paleocene, however, diversity significantly increased in the warmest phases of the late Paleocene. Elsewhere, forests of the Paleocene were characterized as generally species-poor while their diversity did not fully recover until the end of the Paleocene Johnson 
\& Ellis 2002, Wilf \& Johnson 2004), a trend which is also reflected in our reconstruction. This diversity increase throughout the Paleocene is also related to a diversification or first appearance of modern plant species (Collinson 1990, 2000, 2001).

Today, the Amur Region, heterogeneous in terms of topography, climate, and soil, has a very heterogeneous vegetation cover (Starchenko 2009, Borisova \& Starchenko 2018). It includes taiga, coniferous-deciduous forests and forest-steppes, representing the subarctic, cool temperate to warm temperate zones while forests cover about $70 \%$ of this region. Part of the forest zone is occupied by surface waters and swamps. According to our results the Paleocene vegetation cover in the study area fundamentally differed from modern. Based on the low proportion of herbaceous PFTs (0-15.8 \%), our data indicate that the Amur Region was entirely covered by forest vegetation during the Paleocene. Comparable conditions were reconstructed for the Paleocene Primorye (Bondarenko et al. 2020a). The results obtained from the PFT approach again are in accordance with data obtained from IPR approach. According to Kovar-Eder et al. (2008) and Teodoridis et al. (2011), with zonal herb proportions ranging from 5.9 to $29.8 \%$, no open woodland is reconstructed for the Amur Region throughout the Paleocene based on the IPR-vegetation analysis. Thus, a closed forest cover likely existed in the Amur Region throughout the Paleocene. Popova et al. (2013) point out a steep declining trend of the arboreal component in Western Siberia but not before the end of the Eocene. Densely forested areas were also reported from other continental parts such as Northern America where little evidence of wideopen plains has been obtained (Graham 1999: 162-169). In this context it has been assumed that the extinction of large herbivorous dinosaurs may have allowed the forests to grow quite dense (Williams et al. 2009).

\section{Seasonality and monsoon}

The Amur Region presently is under the influence of the EAM (Zhang \& Wang 2008). The modern regime of temperature and humidity of this region is characterized by a pronounced seasonality. Today, MART is at the very high level of $45.2^{\circ} \mathrm{C}$, at a mean, and MARP is around $130 \mathrm{~mm}$. Summer precipitation account for up to $70 \%$ of the MAP, while rainfall in winter amounts to $8 \%$ only (Naprasnikov et al. 1983). The modern RMPwet and RMPdry calculated based on the mean values using station data of Blagoveshchensk (Müller \& Hennings 2000, New et al. 2002), are $23.3 \%$ and $0.9 \%$, respectively (Table 2 ).

All our climatic data suggest a relatively strong seasonal control of the Paleocene climate of the Amur Region (Table 2). The slightly higher-than-present Paleocene WMMTs in combination with significantly higher-than-present CMMTs indicate a lower-than-present seasonality of temperature during the Paleocene, however, MART gradually decreased from ca $18.9-14.2^{\circ} \mathrm{C}$ in the lower part (at depth levels $179.4-220.1 \mathrm{~m}$ ) to ca. $13.5-15.4^{\circ} \mathrm{C}$ in the upper part of the well (at depth levels 130.2-174.3 m).

The pronounced seasonality of precipitation (MPwet $177-270 \mathrm{~mm}$; MPdry as $27-53 \mathrm{~mm}$ ) of the Paleocene cli- mate of the Amur Region significantly fluctuated during the Paleocene but does not show distinct increasing/decreasing trend. The Paleocene MARP was at a higher-than-present level. However, the higher past MPwet coupled with distinctly higher MPdry indicate that, during the Paleocene, the climate of the Amur Region was more humid, in general. The calculated proportions of MPwet and MPdry to yearly precipitation (MPwet: 14.0-22.3 \%; MPdry: 2.0-4.1\%) are almost twice as high compared to present-day (Table 2) and suggest that both, EASM and EAWM were considerably weaker.

Bondarenko et al. (2020b) indicated also pronounced seasonality of climate of Primorye throughout the Paleogene. Utescher et al. (2015) suggested a seasonal control of precipitation in the Cenozoic climate of Primorye. According to this reconstruction, the ratio of the wet month precipitation of the total amount of annual precipitation (RMPwet) used as a proxy for EAM intensity (Jacques et al. 2011) stayed well below the modern value until the earlier part of the late Miocene.

There are extensive literature resources discussing the timing of establishment of the EAM and prevalence of arid climates in the continental interior of Asia, based on various proxies that partly lead to controversial results and conclusions. For example, studies based on thick eolian deposits in northern China (Guo et al. 2002, Qiang et al. 2011), pollen records (Sun \& Wang 2005), and palaeoenvironmental patterns based on geological and geo-biological evidence (Guo et al. 2008, Wang et al. 2014b) constrained the time of the formation of the EAM to 22-25 Ma, i.e. to the Oligocene-Miocene transition. An et al. (2001) suggested that the evolution of the EAM was coupled with phased uplift of the Tibetan Plateau since the late Miocene, while others have claimed that proto-Tibetan highlands already existed throughout the Paleogene (e.g., Wang et al. 2014a, Spicer 2017), and that a monsoon type circulation was already operational during most of the Paleogene (Huber \& Goldner 2012, Hoorn et al. 2012, Quan et al. 2012b, 2014, Wang et al. 2013, Licht et al. 2014, Bosboom et al. 2015). The seasonal precipitation patterns we reconstruct support the assumption of a (considerably weaker-than-present) Paleogene proto-monsoon.

\section{CONCLUSION}

Our data provide the first detailed time series for the early Paleogene climate evolution of the RFE, possibly spanning most of the Paleocene. As a result, the climate of the Amur Region during the Paleocene in general was overall humid, warm temperate in the warmer parts and cool temperate in the coolest part of the studied time-period. The MAT record reconstructed for Core 154 displays a distinct warming trend for the upper part of the succession, most probably coinciding with the declining trend in the global oxygen isotope record throughout the late Paleocene. At the same time there is a trend to more equable climates as evident from declining MART. Palynostratigraphical constraints in our record support the concept of a late Paleocene age for this warming. Shorter-term variability in our MAT record suggests intermittent cooler phases in the earliest 
Thanetian and in the latest Paleocene, possibly correlated with the positive oxygen isotope shift in the global record pre-dating the PETM. The globally cooler conditions near the $\mathrm{K}-\mathrm{T}$ boundary correlate with the highest seasonality of temperature observed in our record. All our climate data suggest relatively strong temperature seasonality and pronounced precipitation seasonality for the Paleocene climate of the Amur Region.

The application of cluster analysis on the palynological dataset reveals a total of four pollen zones that are characterized by differing palynomorph percentages. These zones allow for inter-regional stratigraphic correlations and support the stratigraphical concept suggested by Moiseeva et al. (2018). Diversity evolution in the record testifies an already relatively high level for the earliest Paleocene, however, diversity significantly increased in the warmest phases of the late Paleocene.

Quantitative data obtained from the application of the PFT and IPR approaches allow for tracing vegetation evolution in the Amur Region throughout the early Paleogene. Both methods prove the prevalence of mixed evergreendeciduous forest of mainly warm temperate character having a diverse shrub layer throughout the studied timespan (IPR types: MMF, MMF/BLEF; rarely BLDF/MMF). Herbaceous components are constantly present but attain moderate diversities only $(<10 \%)$. Hence, our vegetation data in general indicate more forested conditions within the studied territory during the Paleocene than at present. The ratio of broadleaved evergreen vs. deciduous PFTs largely co-variates with the MAT record, thus exemplifying the affinity of evergreens to the warmer climate phases. The phase with high diversity of conifer PFTs in the middle part of the succession correlates with an overall lower temperature level. Forests with diverse conifers may represent azonal vegetation connected to increased extension of peat bog facies. The persistent occurrence of PFTs indicative for humid conditions such as mesic herbs and swamp trees (PFTs $1,18)$ coincides with the assumption of humid climate conditions in the Paleocene Amur Region.

All our data suggest a relatively strong seasonal control of the precipitation in the Paleocene Amur Region pointing to the existence of a proto-monsoon. When taking RMPwet and RMPdry as proxies for estimating monsoon intensity it is shown that the values were almost twice as high compared to presentday suggesting considerably weaker EASM and EAWM.

\section{ACKNOWLEDGEMENTS}

The authors are thankful to the anonymous reviewers for carefully revising the manuscript and for their valuable suggestions. This work is a contribution to NECLIME (Neogene Climate Evolution in Eurasia).

\section{LITERATURE CITED}

Akhmetiev, M.A. 1973. Paleocene and Eocene flora of the south of the Far East, their stratigraphic significance and climatic characteristics. Sovetskaya Geologiya 7:14-29 (in Russian). [Ахметьев М.A. 1973. Палеоценовые и эоценовые флоры юга Аальнего Востока, их стратиграфическое значение и климатическая характеристика // Советская Геология. № 7. С. 14-29.].
Akhmetiev, M.A. 2004. The Paleocene and Eocene global climate. Paleobotanical evidences. In: Climate in the epoches of major biospheric transformations (Proceeding of Geological Institute RAN, Vol. 550) (M.A. Semikhatov \& N.M. Chumakov, eds.), pp. 10-43, Geological Institute RAS, Moscow (in Russian) [Ахметьев M.А. 2004. КАимат земного шара в палеоцене и эоцене по Аанным палеоботаники / / КАимат в эпохи крупных биосферных перестроек (Труды ГИН РАН. Вып. 550) / поА реА. М.А. Семихатова, Н.М. Чумакова. Москва: ГИН PAH. C. 10-43].

Akhmetiev, M.A. 2010. Paleocene and Eocene floristic and climatic change in Russia and Northern Kazakhstan. Bulletin of Geosciences 85(1):77-94.

Akhmetiev, M.A. 2015. High-latitude regions of Siberia and northeast Russia in the Paleogene: stratigraphy, flora, climate, coal accumulation. Stratigraphy and Geological Correlation 23(4):421-435.

Akhmetiev, M.A., S.V. Beletskaya, V.F. Morozova \& S.A. Salun 1969. Paleogene and Neogene deposits of the intermontane depressions of the Lower Amur River Region and Western Okhotsk. Sovetskaya Geologiza 7: 9-23 (in Russian). [Ахметьев М.А., Белецкая С.В., Морозова В.Ф., Салун С.А. 1969. Палеогеновые и неогеновые отложения межгорных впадин Нижнего Приамурья и ЗапаАного Приохотья / / Советская Геология. № 7. С. 9-23.].

Akhmetiev, M.A., T.V. Kezina, T.M. Kodrul \& S.R. Manschester 2002. Stratigraphy and Flora of the border layers of Cretaceous and Paleogene of the south-eastern part of the Zeya-Bureya sedimentary basin. In: Special volume, dedicated to the memory of the Corresponding member of the USSR Academy of Sciences, Professor V sevolod Andreevich Vakhrameev (to the 90th anniversary of his birth) (M.A. Akhmetiev, A.B. Herman, M.P. Doludenko \& I.A. Ignatiev, eds.), pp. 275315, GEOS, Moscow: (in Russian). [Ахметьев M.A., Keзина Т.В., Кодрул Т.М., Манчестер С.Р. 2002. Стратиграфия и флора пограничных слоев мела и палеогена юго-восточной части Зейско-Буреинского осаАОчного бассейна // Сборник памяти члена-корреспондента АН СССР, профессора Всеволода Андреевича Вахрамеева (к 90-летию со Аня рожАения) / поА. ред. М.А. Ахметьева, А.Б. Германа, М.П. Аолуденко, И.А. Игнатьева. Москва: ГЕОС. С. 275-315].

Akhmetiev, M.A. \& N.I. Zaporozhets 2017. The climateforming role of Early Paleogene marine currents in high latitudes of Eurasia. Stratigraphy and Geological Correlation 25(2):229-240.

An, Z., J.E. Kutzbach, W.L. Prell \& S.C. Porter 2001. Evolution of Asian monsoons and phases uplift of the Himalayan Tibetan Plateau since Late Miocene times. Nature 411:62-66.

Beerling, D.J. \& D.L. Royer 2011. Convergent Cenozoic $\mathrm{CO}_{2}$ history. Nature Geoscience 4:418-420.

Bondarenko, O.V., N.I. Blokhina, A.-J. Henrot \& T. Utescher 2020a. Paleogene vegetation changes in Primorye, Far East of Russia - a study based on diversity of plant functional types. Geological Journal, DOI:10.1002/gj.3788.

Bondarenko, O.V., N.I. Blokhina, V. Mosbrugger \& T. Utescher 2020b. Paleogene climate dynamics in the Primorye Region, Far East of Russia, based on a Coexistence Approach analysis of palaeobotanical data. Palaeobiodiversity and Palaeoenvironments. 100(1):5-31.

Bondarenko, O.V., N.I. Blokhina \& T. Utescher 2019. Major plant biome changes in the Primorye Region (Far East of Russia) during the Paleogene. Botanica Pacifica 8(1):3-18. 
Borisova, I.G. \& V.M. Starchenko 2018. Phytogeographical regionalization of Amurskaya Oblast. V.L. Komarov Memorial Lectures 66:28-64 (in Russian). [Борисова И.Г., Старченко B.M. 2018. Ботанико-географическое районироваие Амурской области // Комаровские чтения. Вып. 66. С. 28-64].

Bolotnikova, M.D. 1979. Spore-pollen complexes of Tertiary sediments of the western coast of the Sea of Japan. Nauka, Moscow, 196 рp. (in Russian). [Болотникова М.А. 1979. Спорово-пыльцевые комплексы третичных отложений запаАного побережья Японского моря. Москва: Наука. 196 с.].

Bosboom, R., O. Mandic, G. Dupont-Nivet, J.N. Proust, C. Ormukov \& J. Aminov 2015. Late Eocene palaeogeography of the proto-Paratethys Sea in Central Asia (NW China, southern Kyrgyzstan and SW Tajikistan). In: Geological Evolution of Central Asian Basins and the Western Tien Shan Range (Special Publications) (M.F. Brunet, T. McCann \& E.R. Sobel, eds), pp. 1-427, Geological Society, London.

Brattseva, G.M. 1962. New data on the flora bordering between the Cretaceous and the Paleogene in the region of the Zeisko-Bureinskaya depression. Doklady AN USSR 143(1):167-170 (in Russian). [Братцева Г.M. 1962. Новые Аанные о фморе, пограничной межАу мелом и палеогеном, в районе Зейско-Буреинской депрессии // Аоклады АН СССР. Т. 143, № 1. С. 167-170].

Brattseva, G.M. 1964. Spore-pollen spectra of Tsagayan deposits and their geological age. Doklady AN USSR 157(5):1111-1113 (in Russian). [Братцева Г.M. 1964. Спорово-пыльцевые спектры цагаянских отложений и их геологический возраст // Аоклады АН СССР. T. 157, № 5. C. 1111-1113].

Brattseva, G.M. 1965. Pollen and spores of the Maastrichtian deposits of the Far East. Proceeding of Geological Institute AN USSR 120:1-40 (in Russian). [Братцева Г.M. 1965. Пыльца и споры маастрихтских отложений Аальнего Востока // Труды Геологического института АН СССР. Вып. 120. С. 1-40].

Brattseva, G.M. 1969. Palynological studies of Upper Cretaceous and Paleogene of the Far East. Proceeding of Geological Institute AN USSR 207:1-56 (in Russian). Братцева Г.M. 1969. Палинологические исследования верхнего мела и палеогена Аальнего Востока / / Труды Геологического института АН СССР. Вып. 207. С. 1-56].

Brea, M., S.D. Matheos, M.S. Raigemborn, A. Iglesias, A.F. Zucol \& M. Prámparo 2011. Paleoecology and paleoenvironments of Podocarp trees in the Ameghino Petrified forest (Golfo San Jorge Basin, Patagonia, Argentina): Constraints for Early Paleogene paleoclimate. Geologica Acta 9(1):13-28.

Bruch, A.A., T. Utescher \& V. Mosbrugger 2011. Precipitation patterns in the Miocene of Central Europe and the development of continentality. Palaeogeography, Palaeoclimatology, Palaeoecology 304:202-211.

Budrin, V.S. \& N.S. Gromova 1973. On the age of border deposits of Cretaceous and Paleogene on Sakhalin. In: Palynological method in stratigraphy. (Proceedings of the Geological Institute AN USSR. V. 195, new ser.) (E.M. Boitsova, ed.), pp. 138-139 Nauka, Leningrad (in Russian). Булрин В.С., Громова Н.С. 1973. О возрасте пограничных отложений мела и палеогена на Сахалине // Палинологический метод в стратиграфии (Труды Геомогического института АН СССР. Т. 195, нов. сер.) / науч. реА. Е.М. Бойцова. АенинграА: Наука. С. 138-139].
Bugdaeva, E.V., V.S. Markevich, A.P. Sorokin \& Yu.L. Bolotskii 2001. Flora and dinosaurs at the Cretaceous-Paleogene boundary of the Zeya-Bureia Basin. Dal'nauka, Vladivostok, 162 pp. (in Russian). [Бугааева Е.B., Маркевич B.C., Сoрокин А.П., Болотский Ю.А. 2001. ФАора и Аинозавры на границе мела и палеогена Зейско-Буреинского бассейна. 2001. ВАадивосток: Аальнаука. 162 с.].

Charles, A.J., D. Condon, I. Harding, H. Pölike, J. Marshall, Y. Cui, L. Kump \& I. Croudace 2011. Constraints on the numerical age of the Paleocene-Eocene boundary. Geochemistry. Geophysics. Geosystems 12, Q0AA17, https:// doi.org/10.1029/2010GC003426.

Chemekov, Yu.F., I.I. Sei, M.A. Sedova \& L.V. Burilina 1960. Stratigraphy of loose deposits of the Amur-Zeya depression. Sovetskaya Geologiya 2:17-37 (in Russian). [Чемеков Ю.Ф., Сей И.И., Седова М.А., Бурилина А.В. 1960. Стратиграфия рыхлых отложений Амуро-Зейской Аепрессии // Советская Геология. № 2. С. 17-37].

Clementz, M., S. Bajpai, V. Ravikant, J.G.M. Thewissen, N. Saravanan, I.B. Singh \& V. Prasad 2011. Early Eocene warming events and the timing of terrestrial faunal exchange between India and Asia. Geology 39(1):15-18.

Collinson, M.E. 1990. Plant evolution and ecology during the early Cainozoic diversification. Advances in Botanical Research 17:1-98.

Collinson, M.E. 2000. Cenozoic evolution of modern plant communities and vegetation. In: Biotic response to global change the last 145 million years (S.J. Culver \& P.F. Rawson, eds.), pp. 223-243. Cambridge University Press, Cambridge.

Collinson, M.E. 2001. Rise of modern land plants and vegetation. In: Palaeobiology. II (D.E.G. Briggs \& P.R. Crowther, eds.), pp. 113-116. Blackwells, Oxford.

Collinson, M.E. \& J.J. Hooker 2003. Paleogene vegetation of Eurasia: framework for mammalian faunas. Deinsea 10: 41-83 (Special issue: Distribution and migration of Tertiary mammals in Eurasia. A volume in honour of Hans de Bruijn (J.W.F. Reumer \& W. Wessels, eds.)).

Dickens, G.R. 2000. Methane oxidation during the Late Paleocene Thermal Maximum. Bulletin de la Société Géologique de France 171:37-49.

Dickens, G.R., J.R. O’Neil, D.K. Rea \& R.M. Owen 1995. Dissociation of ocean methane hydrate as a cause of the carbon isotope excursion at the end of the Paceocene. Paleoceanography 10(6):965-971.

Fin'ko, V.I. \& E.D. Zaklinskaya 1958. To the question of stratigraphy of loose deposits of the Zeya-Bureya depression. Izvestiya AN USSR, Ser. Geol. 2:25-43 (in Russian). [Финько B.И., Заклинская Е.А. 1958. К вопросу о стратиграфии рыхлых отложений Зейско-Буреинской депрессии // Известия АН СССР, Сер. Геол. № 2. С. 25-43].

François, L., T. Utescher, E. Favre, A.-J. Henrot, P. Warnant, A. Micheels, B. Erdei, J.-P. Suc, R. Cheddadi \& V. Mosbrugger 2011. Modelling late Miocene vegetation in Europe: Results of the CARAIB model and comparison with palaeovegetation data. Palaeogeography, Palaeoclimatology, Palaeoecology 304:359-378.

Fricke, H.C. \& S.L. Wing 2004. Oxygen isotope and paleobotanical estimates of temperature and ${ }^{18} \mathrm{O}$-latitude gradients over North America during the early Eocene. American Journal of Science 304:612-635.

Graham, A. 1999. Late Cretaceous and Cenozoic history of North American vegetation, North of Mexico. Oxford University Press, Oxford, 350 pp. 
Grimm, E.C. 2011. Tilia version 1.7.16 [software]. Illinois State Museum, Springfield, Illinois, USA.

Guo, Z.T., W.F. Ruddiman, Q.Z. Hao, H.B. Wu, Y.S. Qiao, R.X. Zhu, S.Z. Peng, J.J. Wei, B.Y. Yuan \& T.S. Liu 2002. Onset of Asian desertification by $22 \mathrm{Myr}$ ago inferred from loess deposits in China. Nature 416:159-163.

Guo, Z.T., B. Sun, Z.S. Zhang, S.Z. Peng, G.Q. Xiao, J.Y. Ge, Q.Z. Hao, Y.S. Qiao, M.Y. Liang, J.F. Liu, Q.Z. Yin \& J.J. Wei 2008. A major reorganization of Asian climate by the early Miocene. Climate of the Past 4:153-174.

Gutjahr, M., A. Ridgwell, P.F. Sexton, E. Anagnostou, P.N. Pearson, H. Pälike, R.D. Norris, E. Thomas \& G.L. Foster 2017. Very large release of mostly volcanic carbon during the Palaeocene-Eocene Thermal Maximum. Nature 548:573-577.

Hao, H., D.K. Ferguson, G.P. Feng, A. Ablaev, Y.F. Wang \& C.S. Li 2010. Early Paleocene vegetation and climate in Jiayin, NE China. Climate Change 99:547-566.

Henrot, A.-J., T. Utescher, B. Erdei, V. Dury, N. Hamon, G. Ramstein, M. Krapp, N. Herold, A. Goldner, E. Favre, G. Munhoven \& L. Francois 2017. Middle Miocene climate and vegetation model $\mathrm{s}$ and their validation with proxy data. Palaeogeography, Palaeoclimatology, Palaeoecology 467:95-119.

Herman, A.B., M.A. Akhmetiev, T.M. Kodrul, M.G. Moiseeva \& A.I. Yakovleva 2009. Flora development in northeastern Asia and northern Alaska during the Cretaceous-Paleogene transitional epoch. Stratigraphy and Geological Correlation 17(1):79-97.

Hoorn, C., J. Straathof, H.A. Abels, Y.D. Hu, T. Utescher \& G. Dupont-Nivet 2012. A late Eocene palynological record of climate change and Tibetan Plateau uplift (Xining Basin, China). Palaeogeography, Palaeoclimatology, Palaeoecology 344-345:16-38.

Huber, M. \& R. Caballero 2011. The early Eocene equable climate problem revisited. Climate of the Past 7:603-633.

Huber, M. \& A. Goldner 2012. Eocene monsoons. Journal of Asian Earth Sciences 44:3-23.

Inglis, G.N., M.E. Collinson, W. Riegel, V. Wilde, A. Farnsworth, D.J. Lunt, P. Valdes, B.E. Robson, A.C. Scott, O.K. Lenz, B.D.A. Naafs \& R.D. Pancost 2017. Mid-latitude continental temperatures through the early Eocene in Western Europe. Eatrh and Planetary Science Letters 460: 86-96.

Jacques, F.M.B., S.X. Gou, T. Su, Y.W. Xing, Y.J. Huang, Y.S. Li, D.K. Ferguson \& Z. Zhou 2011. Quantitative reconstruction of the late Miocene monsoon climates of southwest China: A case study of the Lincang flora from Yunnan Province. Palaeogeography, Palaeoclimatology, Palaeoecology 304:318-327.

Johnson, K.R. \& Ellis 2002. A tropical rainforest in Colorado 1.4 million years after the Cretaceous-Tertiary boundary. Science 296(5577):2379-2383.

Jones, S.M., M. Hoggett, S.E. Greene \& T.D. Jones 2019 Large Igneous Province thermogenic greenhouse gas flux could have initiated Paleocene-Eocene Thermal Maximum climate change. Nature Communications 10: Article no. 5547.

Kamaeva, A.M. 1990. Stratigraphy and flora of the boundary deposits of Cretaceous and Paleogene of the Zeya-Bureya Depression. Amur Integrated Research Institute DVO AN SSSR, Khabarovsk, 67 pp. (in Russian). [Камаева A.M. 1990. Стратиграфия и флора пограничных отложений мела и палеогена Зейско-Буреинской впадины. Хабаровск:
Амурский комплексный научно-исследовательский институт $\triangle \mathrm{BO}$ АН СССР. 67 с.].

Kezina, T.V. 2000. Cenozoic palynostratigraphy of the Upper Amur River Region. Dal'nauka, Vladivostok, 64 pp. (in Russian). [Кезина Т.В. 2000. Палиностратиграфия кайнозоя Верхнего Приамурья. ВАадивосток: АаАьнаука. 64 с.].

Kezina, T.V. 2004. Stratigraphy of South-Eastern Flanks of the Raichikhinsk Brown Coal Field (the Zeya-Bureya sedimentary basin). Journal of Geoscientific Research of Northeast Asia 7(2):110-119.

Kezina, T.V. 2005. Palynostratigraphy of coal deposits of the Late Cretaceous and Cenozoic of the Upper Amur River Region. Dal'nauka, Vladivostok, 206 pp. (in Russian). [Кезина T.B. 2005. Палиностратиграфия угленосных отложений позАнего мела и кайнозоя Верхнего Приамурья. В^аАивосток: Аальнаука. 206 с.].

Kezina, T.V. 2011. Palynological characterization of the Paleocene Wuyun Formation, People's Republic of China. Stratigraphy and Geological Correlation 19(3):296-309.

Kezina, T.V. \& N.D. Litvinenko 2007. Palynostratigraphy of the Erkovtsy field of brown coal (the Zeya-Bureya sedimentary basin). Stratigraphy and Geological Correlation 15(4):385-400.

Kezina, T.V. \& G.F. Ol'kin 2000. Palynological characteristics of Cenozoic coal-bearing deposits, the Snezhnogorskii locality in the Verkhnyaya Zeya Basin. Stratigraphy and Geological Correlation 8(5):482-490.

Khlonova, A.F. 1969. Spore-pollen characteristics of the Cretaceous deposits of the See-Bureya depression. In: Spore-pollen complexes of the Mesozoic of Siberia and the Far East (I.I. Sharudo, ed.), pp. 34-42, Nauka, Moscow (in Russian). [ХАонова А.Ф. 1969. Спорово-пыльцевая характеристика меловых отложений Зее-Буреинской впадины // Спорово-пыльцевые комплексы мезозоя Сибири и АаАьнего Востока / под реА. И.И. Шарудо. Москва: Наука. С. 34-42].

Knittel, U., S. Suzuki, M.A. Akhmetiev, G. Sun, M. Walia \& C.-H. Hung 2013. 66 $11 \mathrm{Ma}$ single zircon U-Pb date confirms the location of the non-marine K-Pg boundary in the Amur/Heilongjiang River area (Russia, China). Nenes Jabrbuch für Geologie und Paläontologie 270(1):1-11.

Kovar-Eder, J. \& Z. Kvaček 2003. Towards vegetation mapping based on the fossil plant record. Acta Universitatis Carolinae, Geologica 46(4):7-13.

Kovar-Eder, J. \& Z. Kvaček 2007. The integrated plant record (IPR) to reconstruct Neogene vegetation: the IPRvegetation analysis. Acta Palaeobotanica 47(2):391-418.

Kovar-Eder, J., H. Jechorek, Z. Kvaček \& V. Parashiv 2008. The Integrated Plant Record: an essential tool for reconstructing Neogene zonal vegetation in Europe. Palaios 23:97-111.

Kovar-Eder, J. \& V. Teodoridis 2018. The middle Miocene central European plant record revisited widespread subhumid sclerophyllous forests indicated. Fossil Imprint 74(1-2):115-134.

Krasnyi, L.I. (ed.) 1994. Decisions of the IV Interdepartmental Regional Stratigraphic Meeting on Precambrian and Phanerozoic in the South of the Far East and Eastern Transbaikalia. Izdatel'stvo KhGGGP, Khabarovsk, 124 pp. (in Russian). [Peшения IV Межведомственного регионального стратиграфического совещания по докембрию и фанерозою юга Аальнего Востока и Восточного Забайкалья. 1994. Хабаровск: Издательство ХГГГП, 124 с.]. 
Krassilov, V.A. 1976. Tsagayanskaya flora of the Amur Region. Nauka, Moscow, 92 pp. (in Russian). [Красилов B.A. 1976. Цагаянская фмора Амурской области. Москва: Наука. 92 с.].

Kryshtofovich, A.N. \& T.N. Baikovskaya 1966. Upper Cretaceous Tsagayan flora in the Amur Region. In: Selected Workes (A.N. Kryshtofovich, ed.), vol. 1, pp. 184-320, Izdatel'stvo AN USSR, Moscow, Leningrad (in Russian). [Криштофович А.Н., Байковская Т.Н. 1966. Верхнемеловая флора цагаяна в Амурской области // Криштофович А.Н. (ред.), Избранные труды. Москва; Менинград: Издательство АН СССР. Т. 3. С. 184-320].

Kul'kova, I.A. 1973. Palynological studies of the Eocene deposits of the Yano-Indigir lowland. Nauka, Novosibirsk, 116 pp. (in Russian). [Кулькова И.А. 1973. Палинологические исследования эоценовых отложений Яно-ИнАигирской низменности. Новосибирск: Наука. 116 с.].

Li, X., W. Li, P. Chen, X. Wan, G. Li, S. Biao, J. Jiang, J. Liu, D. Yin \& W. Yan 2004. SRIMP U-Pb zircon dating of the uppermost Cretaceous Furao Formation near the Heilong River: an age closest to the $\mathrm{K} / \mathrm{T}$ boundary. Chinese Science Bulletin 49(8):860-862.

Licht, A, M. Van Cappelle, H.A. Abels, J.B. Ladant, J. Trabucho-Alexandre, C. France-Lanord, Y. Donnalieu, J. Vandenberghe, T. Rigaudier, C. Lécuyer, Jr.D. Terry, R. Adriaens, A. Boura, Z. Guo, Aung Naing Soe, J. Quade, G. Dupont-Nivet \& J.J. Jaeger 2014. Asian monsoons in a late Eocene greenhouse world. Nature 513:501-506.

Liu, X.D. \& Z.Y. Yin. 2002. Sensitivity of East Asian monsoon climate to the uplift of the Tibetan Plateau. Palaeogeography, Palaeoclimatology, Palaeoecology 183:223-245.

Liu, X., Q. Guo, Z. Guo, Z.Y. Yin, B. Dong \& R. Smith 2015. Where were the monsoon regions and arid zones in Asia prior to the Tibetan Plateau uplift? National Science Review 2(4):403-416.

Lopatina, D.A. 2004. Vegetation and climate of the Eocene - Miocene, Eastern Sikhote-Alin (from paleobotanical analysis data). Russian Journal of Pacific Geology 23(3):98-112.

Mal'tseva, R.S. \& T.V. Kezina 1985. To the question of the age of the Kivdin flora of the Amur region. In: Geology, magmatism and mineralization of the Amur region. (S.S. Zimin, G.V. Botriakov, eds) pp. 115-120, Far Eastern Scientific Center, AN USSR, Vladivostok (in Russian). [Мальцева Р.С., Кезина T.B. 1985. К вопросу о возрасте кивдинской флоры Приамурья // Геология, магматизм и оруднение Приамурья / под реА. С.С. Зимина и Г.В. Ботрякова. ВАадивосток: АВНЦ АН CCCP. C. 115-120].

Mamontova, I.B. 1975. Spore-pollen characteristics and correlation of continental sediments of the Ushumun Depression. Trudy Sakhalinskogo kompleksnogo nauchno-issledovatel'skogo instituta DVNTs AN SSSR 36: 32-40. (in Russian). [Мамонтова И.Б. 1975. Спорово-пыльцевая характеристика и корреляция континентальных отложений Ушумунской впадины // Труды Сахалинского комплексного научно-исследовательского института АВНЦ АН СССР. Вып. 36. С. 32-40].

Mamontova, I.B. 1977. Palynology of the transitional Cretatious-Paleogene beds in the Amur-Zea depression. In: Paleobotany in the Far East (V.A. Krassilov, ed.), pp. 32-37. Far Eastern Scientific Center of the AN USSR, Vladivostok (in Russian). [Мамонтова И.Б. 1977. Палинофлора переходных слоев верхнего мела и палеогена АмуроЗейской депрессии // Палеоботаника на Аальнем Востоке / под реА. В.А. Красилова. ВАадивосток: Аальневосточный научный центр АН СССР. С. 32-37].
Markevich, V.S. 1995. Cretaceous palynoflora of the north of East Asia. Dal'nauka, Vladivostok, 200 pp. (in Russian). [Mapкевич В.С. 1995. Меловая палинофлора севера Восточной Азии. ВАаАивосток: Аальнаука, 200 с.].

Markevich, V.S., E.V. Bugdaeva \& A.R. Ashraf 2004. Results of study of Arkhara-Boguchan coal field. In: Proceedings of the 3-rd Symp. Cret. Biot. K/T boundary, Heilongizang River Area, China, pp. 41-44, Changchun, China, 31 August - 9 September 2004. Jilin University, Changchun.

Markevich, V.S., E.V. Bugdaeva, A.R. Ashraf \& G. Sun 2011. Boundary of Cretaceous and Paleogene continental deposits in Zeya-Bureya Basin, Amur (Heilongjiang) River region. Global Geology 14(3):144-159.

Markevich, V.S., V.I. Kiselev \& E.V. Bugdaeva 2014. Cretaceous-Paleogene boundary in Amur Region: new data. In: Proceeding of the 3rd All-Russian Scientific Conference: Issues of geology and integrated development of natural resources of East Asia, vol. 2, pp. 41-44, IGNM FEB RAS, Blagoveshchensk (in Russian). [Маркевич В.С., Киселёв В.И., Бугдаева Е.В. 2014. Граница мела и палеогена в Приамурье: новые Аанные // Материалы 3-й всероссийской научной конференции: Вопросы геологии и комплексного освоения природных ресурсов Восточной Азии. БАаговещенск: ИГНМ АВО РАН. Т. 2. С. 41-44].

Meng, J., Ch. Wang, X. Zhao, R. Coe, Y. Li \& D. Finn 2012. India-Asia collision was at $24^{\circ} \mathrm{N}$ and $50 \mathrm{Ma}$ : palaeomagnetic proof from southernmost Asia. Scientific Reports 2: Article no. 925. https://doi.org/10.1038/srep00925.

Moiseeva, M.G., T.M. Kodrul \& A.B. Herman 2018. Early Paleocene Boguchan flora of the Amur Region (Russian Far East): Composition, age and palaeoclimatic implications. Review of Palaeobotany and Palynology 253:15-36.

Morgan, T.J., L.M.E. Percival, E.W. Stokke, J. Frieling, T.A. Mather, L. Riber, B.A. Schubert, B. Schultz, Ch. Tegner, S. Planke \& H.H. Svensen 2019. Mercury anomalies across the Palaeocene-Eocene Thermal Maximum. Climate of the Past 15(1):217-236.

Mosbrugger, V. \& T. Utescher 1997. The coexistence approach - a method for quantitative reconstructions of Tertiary terrestrial palaeoclimate data using plant fossils. Paleogeography, Palaeoclimatology, Palaeoecology 134:61-86.

Mosbrugger, V., T. Utescher, \& D. Dilcher 2005. Cenozoic continental climatic evolution of Central Europe. Proceedings of the National Academy of Sciences 102(42):14964-14969.

Müller, M.J. \& D. Hennings 2000. The Global Climate Data Atlas on CD Rom. University Flensburg, Institute für Geografie, Flensburg.

Muzylev S.A. 1948. Report on geological survey on a scale of 1:1000000 of the Amur-Zeya interfluve in 1943. Trudy Dal'nevostochnoi nauchno-issledovatel'skoi basy AN SSSR 1:48-49 (in Russian). [Музылёв C.A. 1948. Отчет о геологической съёмке масштаба 1:1000000 АмуроЗейского межАуречья в 1943 г. // Труды Аальневосточной научно-исследовательской базы АН СССР. Сер. Геол. Т. 1. С. 48-49.].

Najman, Y., D. Jenks, L. Godin, M. Boudagher-Fadel I, M.E. Garzanti, M. Horstwood \& L. Bracciali 2017. The Tethyan Himalayan detrital record shows that India-Asia terminal collision occurred by $54 \mathrm{Ma}$ in the Western Himalaya. Earth and Planetary Science Letters 459:301-310.

Naprasnikov, A.T., B.A. Bogoyavlenskyi, V.V. Buffal, A.V. Kirichenko, V.V. Aseev \& I.A. Dombrovskyi 1983. Hydroclimatic resources of the Amur Region. Amur branch of Khabarovsk book publishing house, Blagoveshchensk, 68 
pp. (in Russian). [Напрасников А.Т., Богояв енский Б.А., Буфал В.В., Кириченко А.В., Асеев В.В., Аомборовский И.А. 1983. ГиАроклиматические ресурсы Амурской области. Бмаговещенск: Амурское отАеление Хабаровского книжного издательства. 68 с.].

New, M., D. Lister, M. Hulme \& I. Makin 2002. A high-resolution data set of surface climate over global land areas. Climate Research 21:1-25.

Popova, S., T. Utescher, D.V. Gromyko, V. Mosbrugger, E. Herzog \& L. François 2013. Vegetation change in Siberia and the northeast of Russia during the Cenozoic Cooling: a study based on diversity of plant functional types. Palaios 28:418-432.

Prentice, C.I., W. Cramer, S.P. Harrison, R. Leemans, R.A. Monserud \& A.M. Solomon 1992. A global biome model based on plant physiology and dominance, soil properties and climate. Journal of Biogeography 19:117-134.

Prentice, C. \& C. Webb III 1998. Biome 6000, Reconstructing global mid-Holocene vegetation patterns from palaeoecological records. Journal of Biogeography 25:997-1005.

Punekar, J., G. Keller, H. Khozyem, C. Hamming, T. Adatte, A.A. Tantawy \& J.E. Spangenberg 2014. Late Maastrichtian-early Danian high-stress environments and delayed recovery linked to Deccan volcanism. Cretaceous Research 49:63-82

Qiang, X.K., Z.S. An, Y.G. Song, H. Chang, Y.B. Sun, W.G. Liu, H. Ao, J.B. Dong, C.F. Fu, F. Wu, F.G. Lu, Y.J. Cai, W.J. Zhou, J.J. Cao, X.W. Xu \& L. Ai 2011. New eolian red clay sequence on the western Chinese Loess Plateau linked to onset of Asian desertification about $25 \mathrm{Ma}$ ago. Science China Earth Sciences 54:136-144.

Quan, C., (Y.S.) C. Liu \& T. Utescher 2012a. Eocene monsoon prevalence over China: A palaeobotanical perspective. Palaeogeography, Palaeoclimatology. Palaeoecology 365-366: 302-311

Quan, C., (Y.S.) C. Liu \& T. Utescher. 2012b. Paleogene temperature gradient, seasonal variation and climate evolution of northeast China. Palaeogeography, Palaeoclimatology. Palaeoecology 313-314: 150-161.

Quan, C., Z. Liu, T. Utescher, J.H. Jin, J.W. Shu, Y.X. Li \& Y.S. Liu 2014. Revisiting the Paleogene climate pattern of East Asia: a synthetic review. Earth-Science Reviews 139: 213-230.

Sato, T., N. Takahashi, S. Miura, G. Fujie, D.-H. Kang, S. Kodaira, \& Y. Kaneda 2006. Last stage of the Japan Sea back-arc opening deduced from the seismic velocity structure using wide-angle data. Geochemistry, Geophysics, Geosystems 7:1-15

Scheibner, C. \& R.P. Speijer 2008. Decline of coral reefs during late Paleocene to early Eocene global warming. eEarth 3:19-26.

Schulte, P., L. Alegret, Ig. Arenillas, J.A. Arz, P.J. Barton, P.R Bown, T.J. Bralower, G.L. Christeson, Ph. Claeys, Ch.S Cockell, G.S. Collins, A.Deutsch, T.J. Goldin, K. Goto, J.M. Grajales-Nishimura, R.A.F. Grieve, S.P.S. Gulick, K.R. Johnson, W. Kiessling, Ch. Koeberl, D.A. Kring, K.G. MacLeod, T.I. Matsui, J. Melosh, A. Montanari, J.V. Morgan, C.R. Neal, D.J. Nichols, R.D. Norris, E. Pierazzo, G. Ravizza, M. Rebolledo-Vieyra, W.U. Reimold, E. Robin, T. Salge, R.P. Speijer, A.R. Sweet, J. Urrutia-Fucugauchi, V. Vajda, M.T. Whalen \& P.S. Willumsen 2019. The Chicxulub Asteroid Impact and Mass Extinction at the Cretaceous-Paleogene Boundary. Science 327: 1214-1218.
Spicer, R.A. 2017. Tibet, the Himalaya, Asian monsoon and biodiversity - In what ways are they related? Plant Diversity 39:233-244.

Starchenko, V.M. 2009. On the history of the development of flora and vegetation in the Amur Region. Uchyonye Zapiski Zabaikal'skogo gosudarstvennogo universiteta. Estesnvennye Nauki 1:100-104 (in Russian). [Старченко B.M. 2009. К истории развития флоры и растительности Амурской области // Учёные записки Забайкальского государственного университета. Сер. Естественные науки. № 1. C. 100-104].

Steinthorsdottir, M., A.S. Porter, A. Holohan, L. Kunzmann, M. Collinson \& J.C. McElwain 2016. Fossil plant stomata indicate decreasing atmospheric $\mathrm{CO}_{2}$ prior to the EoceneOligocene boundary. Climate of the Past 12:439-454.

Sun G., M. Akhmetiev, Z.M. Dong, A.R. Ashraf, Y.W. Sun, E. Bugdaeva, D.L. Dilcher, L. Golovneva, I. Harding, K. Johnson, T. Kezina, T. Kodrul, J.S. Lu, V. Markevich, H. Nishida, H. Okada, S.O. Park, C.L. Sun, X.Z. Xiong, Y.L. Xing \& Z.L. Zhou 2002. In search of the Cretaceous Tertiary boundary in Heilongjiang River area of China. Journal of Geoscience Research Northeast Asia 5:105-113.

Sun, G., M.A. Akhmetiev, V.S. Markevich, A.R. Ashraf, E. Bugdaeva, P. Godefroit, Yu. Bolotsky, Z.M. Dong, L. Golovneva, H.X. Yang, C.L. Sun, Y.W. Sun, C. Quan, T. Kodrul, T. Kezina, K. Johnson, H. Nishida, D.L. Dilcher, I. Harding \& Y.J. Chen 2011. Late Cretaceous Biota and the Cretaceous-Paleogene $(\mathrm{K}-\mathrm{Pg})$ boundary in Jiayin of Heilongjiang, China. Global Geology 22(1):115-143.

Sun, G., Z.M. Dong, M.A. Akhmetiev, V.S. Markevich, A.R. Ashraf, P. Godefroit, D.L. Dilcher, C.L. Sun, Y.W. Sun, C. Quan, L. Golovneva, E. Bugdaeva, Yu. Bolotsky, S. Suzuki, T. Kodrul, H. Nishida, T. Kezina, I. Harding, H.X. Yang, W.C. Ge, Y.J. Chen \& T. Yang 2014. Late Cretaceous-Paleocene Biota and the K-Pg Boundary From Jiayin of Heilongjiang, China With Discussion on the Extinction of Dinosaurs. Shanghai Scientific \& Technological Education Publishing House, Shanghai.

Sun, G., C. Quan, C.L. Sun, Y.W. Sun, K.L. Luo \& J.S. Lü 2005. Some new knowledge on subdivisions and age of Wuyun Formation in Jiayin of Heilongjiang, China. Journal of Jilin University (Earth Science Edition) 35(2):137142 (in Chinese with English abstract).

Sun, X. \& P. Wang 2005. How old is the Asian monsoon system? Palaeobotanical records from China. Palaeogeography, Palaeoclimatology, Palaeoecology 222:181-222.

Suzuki, S. 2004. Fission-track zircon age of a tuff sample from the Tsagavan Formation, the Amur River area, the Russian Far East. In: Proceedings of the 3rd Symposium Cretaceous Biota, K/T Boundary, Heilongjiang River Area, China, pp. 75-76, Changchun.

Suzuki, S., G. Sun, U. Knittel, T. Danhara \& H. Iwano 2011. Radiometric zircon ages of a tuff sample from the Baishantou Member of Wuyun Formation, Jiavin: a contribution to the search for the K-T boundary in Heilongjian River area, China. Acta Geologica Sinica 85(6):1351-1358.

Tada, R., H.B. Zheng \& P.O. Clift 2016. Evolution and variability of the Asian monsoon and its potential linkage with uplift of the Himalaya and Tibetan Plateau. Progress in Earth and Planetary Science 3(4):1-26.

Teodoridis, V., J. Kovar-Eder, P. Marek, Z. Kvaček \& P. Mazouch 2011. The integrated plant record vegetation analysis: internet platform and online application. Acta Musei Nationalis Pragae, Ser. B 67(3-4):159-165. 
Utescher, T., O.V. Bondarenko \& V. Mosbrugger 2015. The Cenozoic Cooling - continental signals from the Atlantic and Pacific side of Eurasia. Earth and Planetary Science Letters 415:121-133.

Utescher, T., A.A. Bruch, B. Erdei, L. François, D. Ivanov, F.M.B. Jacques, A.K. Kern, (Y.S.) C. Liu, V. Mosbrugger \& R.A. Spicer 2014. The coexistence approach - theoretical background and practical considerations of using plant fossils for climate quantification. Palaeogeography, Palaeoclimatology, Palaeoecology 410:58-73.

Utescher, T., B. Erdei, L. François \& V. Mosbrugger 2007. Tree diversity in the Miocene forests of Western Eurasia. Palaeogeography, Palaeoclimatology, Palaeoecology 253:242-266.

Utescher, T. \& V. Mosbrugger 2007. Eocene vegetation patterns reconstructed from plant diversity - A global perspectives. Palaeogeography, Palaeoclimatology, Palaeoecology 247: $243-271$

Utescher, T. \& V. Mosbrugger 2018. The Palaeoflora Database. Available at http://www.palaeoflora.de. Last accessed 08 August 2020.

Utescher, T., V. Mosbrugger, D. Ivanov \& D.L. Dilcher 2009. Present-day climatic equivalents of European Cenozoic climates. Earth and Planetary Science Letters 284(34):544-552.

Varnavskii, V.G., A.K. Sedykh \& V.I. Rybalko 1988. Paleogene and Neogene Priamurye and Primorye. DVO AN USSR, Vladivostok, 184 pp. (in Russian). [Варнавский В.Г., Седых А.К., Рыбалко В.И. 1988. Палеоген и неоген Приамурья и Приморья. ВАадивосток: АВО АН СССР. 184 с.].

Wang, Zh., Y. Shen \& Zh. Pang 2018. Three main stages in the uplift of the Tibetan Plateau during the Cenozoic period and its possible effects on Asian aridification: A review. Climate of the Past. https://doi.org/10.5194/cp2018-64.

Wang, B., J. Liu, H.J. Kim, P.J. Webster, S.Y. Yim \& B. Xiang 2013. Northern Hemisphere summer monsoon intensified by mega-El Nino/southern oscillation and Atlantic multidecadal oscillation. Proceedings of the National Academy of Sciences 110:5347-5352.

Wang, C.S., J. Dai, X. Zhao, Y. Li, S.A. Graham, D. He, B. Ran \& J. Meng 2014a. Outward-growth of the Tibetan Plateau during the Cenozoic: a review. Tectonophysics 62:1-43.

Wang, P.X., B. Wang, H. Cheng, J. Fasullo, Z.T. Guo, T. Kiefer \& Z.Y. Liu 2014b. The global monsoon across timescales: coherent variability of regional monsoons. Climate of the Past 10:2007-2052.

Westerhold, T., U. Röhl, H.K. McCarren \& J.C. Zachos 2009. Latest on the absolute age of the Paleocene Eocene Thermal Maximum (PETM): New insights from exact stratigraphic position of key ash layers +19 and -17. Earth and Planetary Science Letters 287:412-419.

Wieczorek, R, M.S. Fantle, L.R. Kump \& G. Ravizza 2013. Geochemical evidence for volcanic activity prior to and enhanced terrestrial weathering during the Paleocene Eocene Thermal Maximum. Geochemistry. Cosmochemistry Acta 119:391-410.

Wilf, P. 2000. Late Paleocene-early Eocene climate changes in southwestern Wyoming: paleobotanical analysis. Geological Society of America Bulletin 112:292-307.

Wilf, P. \& K.R. Johnson 2004. Land plant extinction at the end of Cretaceous: a quantitative analysis of the North Dakota megaflora record. Paleobiology 30:347-368.
Willard, D.A., T.H. Donders, T. Reichgelt, D.R.Greenwood, F. Sangiorgi, F. Peterse, K.G.J. Nierop, J. Frieling, S. Schouten \& A. Sluijs 2019. Arctic vegetation, temperature, and hydrology during Early Eocene transient global warming events. Global and Planetary Change 178:139-152.

Williams, A., N.J. Bax, R.J. Kloser, F. Althaus, B. Barker \& G. Keith 2009. Australia's deep-water reserve network: implications of false homogeneity for classifying abiotic surrogates of biodiversity. ICES Journal of Marine Science 66:214-224.

Willis, K.J. \& J.C. McElwain 2002. The evolution of plants. Oxford University Press, Oxford, 378 pp.

Wing, S.L., F. Herrera, C.A. Jaramillo, C. Gómez-Navarro, P. Wilf \& C.C. Labandeira 2009. Late Paleocene fossils from the Cerrejón Formation, Colombia, are the earliest record of Neotropical rainforest. Proceedings of the National Academy of Sciences 106(44):18627-18632.

Woodburne, M.O., G.F. Gunnell \& R.K. Stucky 2009. Climate directly influences Eocene mammal faunal dynamics in North America. Proceedings of the National Academy of Sciences 106(32):13399-13403.

Yamamoto, T. \& N. Hoang 2009. Synchronous Japan Sea opening Miocene fore-arc volcanism in the Abukuma Mountains, NE Japan: an advancing hot asthenosphere flow versus Pacific stab melting. Lithos 112:575-590.

Yavorovsky, P.K. 1911. A brief outline of the southern part of the Zeisko-Bureinskaya Tertiary area. Geological research in the goldbearing region of Siberia, vol. 11. Tipografia M.M. Stasyulevicha, Saint-Petersburg (in Russian). [Яворовский П.К. 1911. Краткий очерк южной части Зейско-Буреинской третичной площаАи. Геологические исследования в золотоносной области Сибири. Санкт-Петербург: Типография М.М. Стасюлевича. Вып. 11].

Zachos, J.C., G.R. Dickens \& R.E. Zeebe 2008. An Early Cenozoic perspective on greenhouse warming and carbon-cycle dynamics. Nature 451:279-283.

Zaklinskaya, E.D., Brattseva G.M. \& V.A. Krassilov 1977. On the palynoflora of the Tsagaian stratotype. In: Paleobotany in the Far East (V.A. Krassilov, ed.), pp. 28-31, Far Eastern Scientific Center of the AN USSR, Vladivostok (in Russian). [Заклинская Е.А., Братцева Г.М., Красилов В.А. 1977. О палинофлоре стратотипа цагаянской свиты // Палеоботаника на Аацьнем Востоке / под реА. В.А. Красилова. ВАадивосток: Аальневосточный научный центр АН СССР. С. 28-31].

Zhang, S.P. \& B. Wang 2008. Global monsoon summer rainy seasons. International Journal of Climatology 28:1563-1578.

Zhang, Q.-Q., T. Smith, J. Yang \& C.-S. Li 2016. Evidence of a cooler continental climate in East China during the warm Early Cenozoic. PLoS ONE 11(5): e0155507.

Ziva, M.V. 1973. Palynological characteristics of the Paleogene deposits of the Amur-Zeya Depression. In: Kainofit palynology (E.D. Zaklinskaya, ed.), pp. 89-93, Nauka, Moscow (Proceedings of the Third International Palynological Conference) (in Russian). [Зива M.В. Паминологическая характеристика палеогеновых отложений Амуро-Зейской впадины // Палинология кайнофита / под ред. Е.А Заклинской. Москва: Наука. С. 89-93. (Труды Третьей МежАународной палинологической конференции). 